Check for updates

Cite this: New J. Chem., 2019, 43, 11771

Received 1st May 2019 . Accepted 1st July 2019

DOI: $10.1039 / c 9 n j 02245 \mathrm{~g}$

rsc.li/njc

\section{Release of reactive selenium species from phthalic selenoanhydride in the presence of hydrogen sulfide and glutathione with implications for cancer research $\dagger$}

\author{
Ammar Kharma, (D) ab Anton Misak, (D) a Marian Grman, (D) a Vlasta Brezova, (D) \\ Lucia Kurakova, (D) ${ }^{d}$ Peter Baráth, (D) e Claus Jacob, (D) ${ }^{b}$ Miroslav Chovanec, (D) \\ Karol Ondrias (D) and Enrique Domínguez-Álvarez (D)*g
}

\begin{abstract}
The last decade has witnessed a renewed interest in selenium (Se) as an element able to prevent a range of illnesses in humans, mainly through supplementation. However, such supplementation relies on species such as sodium selenite or selenomethionine, which proved to have limited solubility and bioavailability, thus leading to limited activity. To overcome this limitation, other selenium species need to be explored, such as phthalic selenoanhydride (R-Se), which is soluble in physiological media. R-Se releases various reactive selenium species (RSeS), including hydrogen selenide $\left(\mathrm{H}_{2} \mathrm{Se}\right)$, that can interact with cellular components, such as glutathione $(\mathrm{GSH})$ and hydrogen sulfide $\left(\mathrm{H}_{2} \mathrm{~S}\right)$. This interplay between $\mathrm{R}$-Se and the cellular components provides a sophisticated biochemical release mechanism that could be behind the noteworthy biological activities observed for this compound. In order to investigate the interactions of phthalic chalcogen anhydrides with $\mathrm{H}_{2} \mathrm{~S}$ or $\mathrm{GSH}$, we have employed UV-vis spectrophotometry, electron paramagnetic resonance spectroscopy (EPR) and plasmid DNA (pDNA) cleavage assay. We found that apart from R-Se, the other analogues do not have the ability to scavenge the ${ }^{\bullet} \mathrm{CPTIO}$ radical or to cleave pDNA on their own. In contrast, the scavenging potency for the ${ }^{\circ} \mathrm{CPTIO}$ radical and for the $\mathrm{O}_{2}{ }^{--}$radical exerted by $\mathrm{R}$-Se and its sulfur analogue (R-S) significantly increased when they were evaluated in the presence of $\mathrm{H}_{2} \mathrm{~S}$. However, GSH only changed the radical scavenging activity of R-Se. These new discoveries may explain some of the biological activities associated with this class of compounds and open a new approach to ascertain the possible mechanisms underlying their biological actions.
\end{abstract}

\title{
Introduction
}

${ }^{a}$ Institute of Clinical and Translational Research, Biomedical Research Center, University Science Park for Medicine, Slovak Academy of Sciences, Dúbravská cesta 9, 84505 Bratislava, Slovak Republic

${ }^{b}$ Division of Bioorganic Chemistry, School of Pharmacy, Saarland University, Campus B2 1, D-66123 Saarbruecken, Germany

${ }^{c}$ Faculty of Chemical and Food Technology, Slovak University of Technology, Radlinskeho 9, 81237 Bratislava, Slovak Republic

${ }^{d}$ Department of Pharmacology and Toxicology, Faculty of Pharmacy, Comenius University, Ulica Odbojárov 10, 83232 Bratislava, Slovak Republic

${ }^{e}$ Institute of Chemistry, Slovak Academy of Sciences, Dúbravská cesta 9, 84538 Bratislava, Slovak Republic

${ }^{f}$ Cancer Research Institute, Biomedical Research Center, University Science Park for Medicine, Slovak Academy of Sciences, Dúbravská cesta 9, 84505 Bratislava, Slovak Republic

${ }^{g}$ Instituto de Química Orgánica General, Consejo Superior de Investigaciones Cientificas (IQOG, CSIC), Juan de la Cierva 3, 28006 Madrid, Spain.

E-mail:e.dominguez.alvarez@csic.es

$\dagger$ Electronic supplementary information (ESI) available. See DOI: 10.1039/c9nj02245g
Selenium (Se) is an essential element for human health and its deficiency causes severe disorders, such as Keshan or KashinBeck diseases, which are endemic in farming self-sufficient regions with low levels of Se in the soil. ${ }^{1,2}$ Both Se-containing compounds and the Se atom present in the active sites of 25 mammalian selenoproteins identified so far participate in key cellular and physiological processes, as well as diseases such as cancer, inflammation, immunity, type 2 diabetes or liver diseases. ${ }^{3-8}$ However, the molecular mechanism of action is not fully understood yet for some of these selenoproteins.

During recent years, Se-compounds have gained substantial interest as $\mathrm{H}_{2} \mathrm{Se}$ donors, as potential anti-cancer agents or as selenocompounds with potential use in selenium supplementation. ${ }^{8-11}$ Among other effects of Se-compounds related to cancer, they could induce apoptosis in cancer cells through the production of Reactive Oxygen Species (ROS), thus 
inducing oxidative stress (OS) ${ }^{12,13}$ Furthermore, certain Secompounds can damage DNA. Then, they may not protect against cancer and other chronic diseases, and can even cause or enhance some types of cancer. These facts indicate that Se may exert a broad pattern of toxic effects. ${ }^{14,15}$ The exact mechanisms underlying the beneficial and toxic effects of Se-compounds are not fully understood yet and they are still under intensive investigation, due to the interest in the potential applications of this dual behaviour: these pro-oxidant/antioxidant Se-compounds could act as novel cellular redox modulators.

In this context, the accessibility and reactivity of the selenols (mainly deprotonated at biological $\mathrm{pH}$ values) and selenol-derived compounds, such as Se-methyl selenocysteine and diselenides, ${ }^{16-19}$ may be behind the reported chemopreventive activity of different Se-containing compounds, which has been reviewed extensively by numerous authors. ${ }^{11,20-25}$ Several mechanisms have been proposed to explain the chemopreventive activity, such as the direct scavenging of free radicals, ${ }^{26,27}$ the amelioration of the toxic effects of anticancer drugs, ${ }^{28}$ the glutathione peroxidase (GPx)-like activity, ${ }^{29,30}$ the protection from toxic elements such as arsenic by protecting PC12 cells from arsenic induced oxidative stress ${ }^{31}$ or the protection from radiotherapy, ${ }^{32}$ and the modulation of the intracellular redox homeostasis ${ }^{33}$ and of the protein kinases. ${ }^{34}$

In the last twenty years, $\mathrm{H}_{2} \mathrm{~S}\left(\mathrm{H}_{2} \mathrm{~S} / \mathrm{HS}^{-} / \mathrm{S}^{2-}\right)$ has been emerging as a new gaseous signalling molecule besides nitric oxide $\left({ }^{\bullet} \mathrm{NO}\right)$ and carbon monoxide (CO). $\mathrm{H}_{2} \mathrm{~S}$ is produced endogenously in almost all mammalian cells and affects many physiological and pathological processes. ${ }^{35-37} \mathrm{H}_{2} \mathrm{~S}$ has mostly beneficial effects under conditions of oxidative stress by reacting with reactive oxygen and nitrogen species. ${ }^{38-42}$ It has both pro- and anticancer effects depending on the cell type, concentration and interaction with other cellular molecules. ${ }^{43-45}$ Glutathione (GSH) is another intracellular natural antioxidant, which has many biological roles including modulation of cellular redox homeostasis and protection against reactive oxygen and nitrogen species. ${ }^{46,47}$ As has been determined in previous work, sodium selenite $\left(\mathrm{Na}_{2} \mathrm{SeO}_{3}\right)$ and selenium tetrachloride $\left(\mathrm{SeCl}_{4}\right)$ have the ability to interact separately with GSH and $\mathrm{H}_{2} \mathrm{~S}$. This fact could be behind their biological effects. ${ }^{48}$ However, as mentioned above, sodium selenite can have reduced bioavailability and can also exert toxic effects. ${ }^{14,15}$ Thus, it is desirable to move towards novel Se-containing compounds that retain this observed ability to interact with relevant sulfur compounds (herein, GSH and $\mathrm{H}_{2} \mathrm{~S}$ ) and, at the same time, show reduced toxicity in comparison with sodium selenite. This would improve the applicability of these new selenium-based redox modulators and simultaneously opens a new approach in Se-supplementation, by finding redox-active derivatives with less toxicity.

In this context, our previous data showed promising chemopreventive, antiproliferative, cytotoxic, free radical scavenging, pro-apoptotic and multidrug-resistance (MDR) reversing activity of phthalic selenoanhydride (R-Se, Fig. 1), the Se-analogue of phthalic-anhydride. ${ }^{49-52}$ Probably, these reported biological activities are directly related to the Se atom, as no relevant biological effects were displayed by its oxygen analogue, phthalic anhydride (R-O). ${ }^{51} \mathrm{~A}$ hypothesis which may explain the amazing
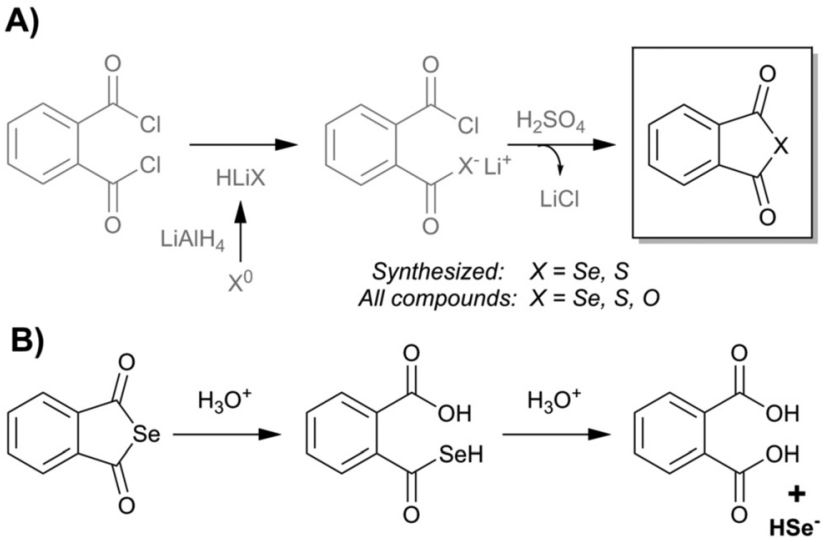

Fig. 1 (A) Chemical structure of the chalcogen derivatives of phthalic anhydride. $\mathrm{X}=\mathrm{Se} \rightarrow \mathrm{R}-\mathrm{Se} ; \mathrm{S} \rightarrow \mathrm{R}-\mathrm{S} ; \mathrm{O} \rightarrow \mathrm{R}-\mathrm{O}$. Synthetic procedure for $\mathrm{R}-\mathrm{Se}$ and R-S. (B) Hypothesized reactions that would lead to the release of hydrogen selenide $\left(\mathrm{H}_{2} \mathrm{Se}\right)$ from $\mathrm{R}$-Se in physiological media.

biological properties of R-Se draws attention to the lability of the CO-Se chemical bond. ${ }^{49}$ This lability suggests the interesting possibility that R-Se behaves in the organism as a prodrug: it enables the internalization of the compound in the cells and once inside it can release selenium slowly inside the cell, in the form of $\mathrm{H}_{2} \mathrm{Se}$, of other uncharged Se-species such as nanoparticles of selenium or of charged Se-anions able to interact swiftly with cellular components. ${ }^{49,51}$ Due to their particular chemical affinity towards thiol-containing agents, such as hydrogen sulfide $\left(\mathrm{H}_{2} \mathrm{~S}\right)$ or glutathione (GSH), and with the enzymes and proteins which are components of the cell thiolstat, such reactivity may initiate pronounced biological responses. In this way, R-Se could be a very simple, elegant and straightforward method to transport selenium inside cells and, at the same time, it would enable its release in an "activated" form as a reactive selenium species, ready to exert immediately a wide variety of biological effects. Besides, these compounds have been proven in previous studies to exert a selective action to be less toxic in non-tumour cells than in cancer cells. ${ }^{49,51}$ Thus, they could be used as safer redox modulators.

Herein, we have studied further the possible mechanism(s) underlying these initial promising biological activities of R-Se, and we will ascertain if these hypothesized interactions with $\mathrm{H}_{2} \mathrm{~S}$ and GSH take place effectively. The activities of R-O and phthalic thioanhydride (R-S) were examined in parallel for comparison. Since $\mathrm{H}_{2} \mathrm{~S}$ and GSH interact with several biologically active molecules, modulating their activities, ${ }^{42,46-48,53}$ the interactions of $\mathrm{H}_{2} \mathrm{~S}$ and $\mathrm{GSH}$ with these three phthalic anhydride derivatives and their molecular consequences were also analysed, expecting that in these instances R-Se would be the most reactive one thanks to its higher expected reactivity. The reduction of the - cPTIO and superoxide $\left(\mathrm{O}_{2}{ }^{--}\right)$radicals, and plasmid DNA (pDNA) cleavage assay were employed to monitor these consequences. We show that only R-Se displays any significant biological activity on its own. This activity was augmented considerably when tested in combination with $\mathrm{H}_{2} \mathrm{~S}$ or GSH. In contrast, GSH showed no impact on the activities of R-S or of R-O, whilst $\mathrm{H}_{2} \mathrm{~S}$ was efficient to some extent in this context. Hence, the products of the $\mathrm{H}_{2} \mathrm{~S}$ or 
GSH interaction with R-Se and R-S show free radical scavenging properties and appear to cleave pDNA, potentially explaining some of their biological activities.

\section{Results and discussion}

To unveil the possible mechanisms underlying the reported activities of R-Se against cancer, we have designed different experiments with R-Se, R-S and R-O, such as mass spectrometry (ESI-MS), spectrophotometrically-monitored radical scavenging and electron paramagnetic resonance (EPR), in an attempt to ascertain how this promising Se-containing compound can interact with different cellular redox targets.

\section{Chemistry}

In the present work, we have evaluated three chalcogen phthalic anhydrides, as shown in Fig. 1: phthalic selenoanhydride $(\mathrm{X}=\mathrm{Se} \rightarrow \mathrm{R}-\mathrm{Se})$, phthalic thioanhydride $(\mathrm{X}=\mathrm{S} \rightarrow \mathrm{R}-\mathrm{S})$ and phthalic anhydride $(\mathrm{X}=\mathrm{O} \rightarrow \mathrm{R}-\mathrm{O})$, as well as phthalic acid (R-OH). R-O and R-OH were commercially available, whereas R-Se and R-S were synthesized following an adaption of the procedure previously described for the synthesis of R-Se (Fig. 1). ${ }^{49}$

In brief, elemental selenium or sulfur is reduced with lithium aluminium hydride, and the in situ formed hydrogen chalcogenide attacks the phthaloyl chloride to form a reactive intermediate. Sulphuric acid is added to form the desired final $\mathrm{R}-\mathrm{Se}$ or R-S. Compounds were isolated in the form of stable solids, whose purity was assessed through NMR and LC-MS.

\section{ESI-MS}

R-Se showed a complex pattern of fragmentation (Fig. 2) in the ESI-MS (electrospray ionization mass spectrometry) spectrum taken in a $50 \%$ methanol $/ \mathrm{H}_{2} \mathrm{O}$ solution (Fig. 3). The possible fragments corresponding to the main peaks observed in ESI are suggested in Fig. 2.

The $\mathrm{M}^{+} \mathrm{H}$ molecular peak of $\mathrm{R}$-Se is easily recognisable thanks to the characteristic isotopic pattern of the Se-containing fragments, and the remaining peaks of low $\mathrm{m} / \mathrm{z}$ can be assigned to specific fragments (Fig. 2). Briefly, the protonated molecular peak $(\mathrm{m} / z=212.94487)$ is attacked by methanol to generate the fragment with $m / z=244.97104$ (also with the characteristic

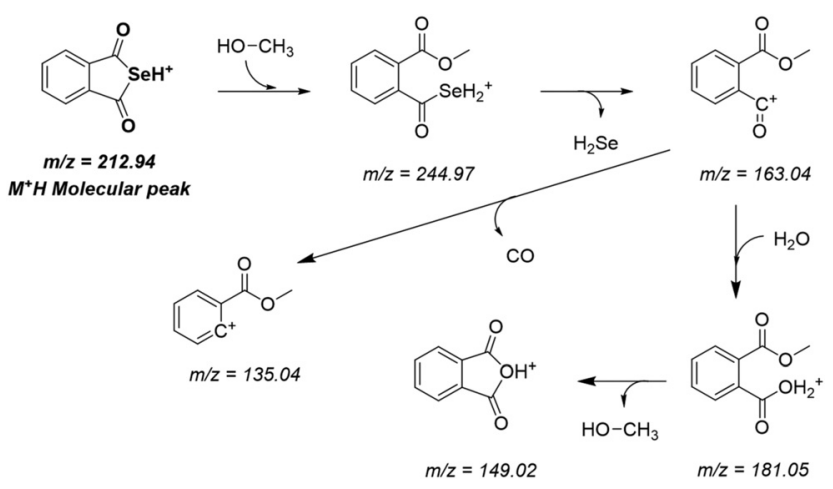

Fig. 2 Hypothesized fragmentation pattern for protonated R-Se in ESI-MS. isotopic pattern of Se). This fragment loses a molecule of hydrogen selenide, leading to $\mathrm{m} / z=163.03906$, which can suffer additional fragmentation (release of $\mathrm{CO}, m / z=135.04408$ ) or can incorporate a molecule of water to later generate protonated $\mathrm{R}-\mathrm{O}$ $(\mathrm{m} / z=181.04956)$. The majority of these peaks can be seen when R-Se is analysed together with $\mathrm{Na}_{2} \mathrm{~S}$ (Fig. 4). The remaining peaks, especially those with $m / z>245$, are the result of complex couplings with other R-Se molecules/fragments, and with water or with the solvent (methanol). The low abundance of the protonated molecular peak in the ESI-MS spectrum may be an indicator of the readiness of the R-Se compound to react with different compounds, and this reactivity can explain the biological activities found so far for this bioactive compound.

When $\mathrm{Na}_{2} \mathrm{~S}$ is added to the R-Se solution in $50 \%$ methanol/ $\mathrm{H}_{2} \mathrm{O}$ (Fig. 4), the protonated molecular peak of R-Se $(\mathrm{m} / z=$ 212.94487) disappears, although $m / z=244.97110$ (the result of methanol addition to this peak and also with the Se isotopic pattern) can be observed, but with a significant lower abundance than in the spectrum of R-Se alone. It is also possible to observe the peaks of lower $m / z$ that were hypothesized above in Fig. $2: m / z=135.04414, m / z=149.02, m / z=163.03908$ and $m / z=181.04958$. Besides, new peaks appear. The most relevant of them is $m / z=197.02664$, which is the equivalent of $m / z=$ 244.97110 but replacing the Se atom by sulfur (Fig. 4, inset). This peak can be formed through the coupling of $\mathrm{H}_{2} \mathrm{~S}$ (generated in situ from $\mathrm{Na}_{2} \mathrm{~S}$ ) with $m / z=163.03908$. Finally, two peaks $(\mathrm{m} / \mathrm{z}=266.95303$ and $\mathrm{m} / \mathrm{z}=219.00859)$ with a difference of $48 \mathrm{Da}$ are found, a difference that can be attributed to a Se-S change, taking into account that the first peak presents the characteristic isotopic pattern of Se. Tentative structures that could explain these two peaks are the polyhydroxy-containing compounds drawn in the Fig. 4 inset. In any case, the absence of the R-Se protonated molecular peak and the two sulfurcontaining peaks $(\mathrm{m} / z=197.02664$ and $\mathrm{m} / z=219.00859)$ together is indicative of an interaction between R-Se and $\mathrm{Na}_{2} \mathrm{~S}$.

According to the data obtained, ESI-MS experiments show how this Se-compound, in the electrospray ionization conditions, suffers specific fragmentation (Fig. 2) and how it forms complex couplings with the solvent and other R-Se molecules/fragments (Fig. 3), indicating that this compound has high reactivity. This fact could be indicative of potential interactions of R-Se with reactive species present in the cell, such as ROS, Reactive Nitrogen Species (RNS) and the sulfur compounds of the redox thiolstat. To prove this hypothetical interaction between R-Se and sulfur species present in cells such as $\mathrm{H}_{2} \mathrm{~S}$, we also applied the ESI-MS methodology to a mixture of R-Se and $\mathrm{Na}_{2} \mathrm{~S}$ (Fig. 4). In this second ESI-MS spectrum, it is observed how the peaks of the initial R-Se are practically irrelevant, whereas its fragment peaks are the main peaks. Additionally, new peaks related to coupling of its fragments with the added sulfur atoms start to be observed, proving also the reaction between the two chalcogen compounds.

\section{Results of the reduction of 'cPTIO by phthalic-anhydride derivatives and $\mathrm{H}_{2} \mathrm{~S}$}

Since $\mathrm{H}_{2} \mathrm{~S}$ is endogenously produced in living organisms, we studied the interaction of $\mathrm{H}_{2} \mathrm{~S}$ with R-Se. We observed that $\mathrm{H}_{2} \mathrm{~S}$ 


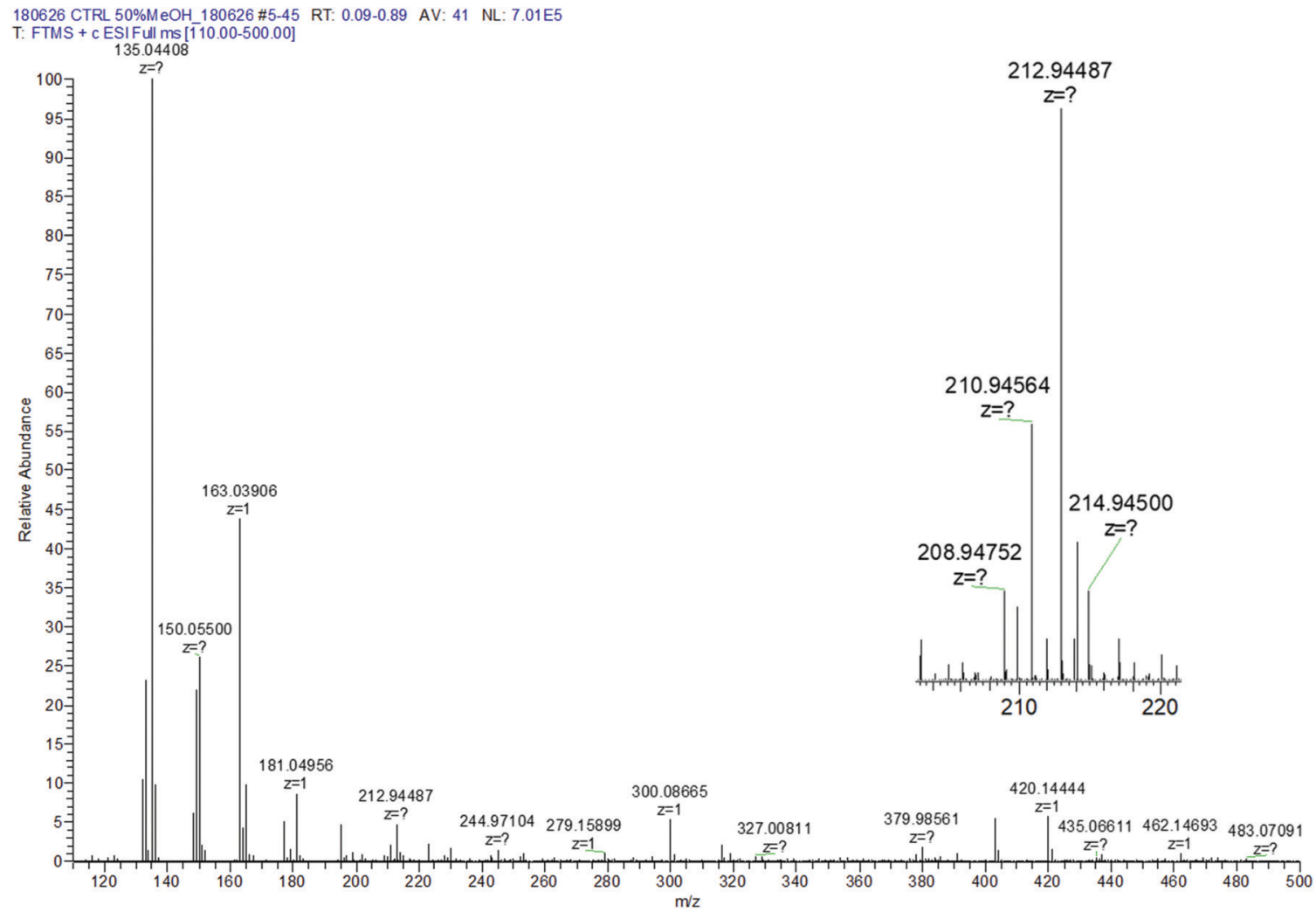

Fig. 3 Control R-Se ESI spectrum in $50 \%$ methanol/ $\mathrm{H}_{2} \mathrm{O}$. Inset: Zoom of the protonated molecular peak showing the characteristic isotopic pattern of Se.

interacts with R-Se. Since $\mathrm{H}_{2} \mathrm{~S}$ and Se derivatives were reported to interact with radicals, ${ }^{54}$ it was of high interest to reveal whether the products of the $\mathrm{H}_{2} \mathrm{~S} / \mathrm{R}$-Se reaction interact with radicals and how this interaction is unique in comparison to other phthalic-anhydride derivatives. Therefore, we studied the potency of $\mathrm{H}_{2} \mathrm{~S}$, R-Se, R-S, R-O and R-OH and the interaction products of $\mathrm{H}_{2} \mathrm{~S} / \mathrm{R}-\mathrm{Se}, \mathrm{H}_{2} \mathrm{~S} / \mathrm{R}-\mathrm{S}, \mathrm{H}_{2} \mathrm{~S} / \mathrm{R}-\mathrm{O}$ and $\mathrm{H}_{2} \mathrm{~S} / \mathrm{R}-\mathrm{OH}$ to reduce the ${ }^{\circ}$ cPTIO radical.

$\mathrm{H}_{2} \mathrm{~S}$ potentiates R-Se and R-S (but not R-O or R-OH) in reducing ${ }^{\circ}$ CPTIO. Since $\mathrm{H}_{2} \mathrm{~S}$ is endogenously produced in organisms and exogenous $\mathrm{H}_{2} \mathrm{~S}$ donors are being considered to be used in medicine, we have studied the interaction of $\mathrm{H}_{2} \mathrm{~S}$ with anhydride derivatives and the ability of the products of this interaction to reduce the ${ }^{-\mathrm{CPTIO}}$ radical. $\mathrm{H}_{2} \mathrm{~S}$ in the presence of R-Se or R-S, but not R-O or R-OH, significantly increased the rate and potency of the compounds to reduce ${ }^{\circ} \mathrm{CPTIO}$ (Fig. 5A, inset, Fig. 5B and 6).

Notably, 6.25, 12.5 and $25 \mu \mathrm{M}$ of R-Se in the presence of $100 \mu \mathrm{M} \mathrm{H}_{2} \mathrm{~S}$ had two time-dependent phases of decreasing the concentration of $100 \mu \mathrm{M}{ }^{\circ} \mathrm{cPTIO}$. The first was a fast decrease (in $\leq 2 \mathrm{~min}$ ) followed by a second gradual decrease (Fig. 6A). On the other hand, $6.25,12.5$ and $25 \mu \mathrm{M}$ of R-S decreased ${ }^{\circ} \mathrm{CPTIO}$ in the first phase slower than what was observed when R-Se was employed ( $\leq 5 \mathrm{~min}$ ), but later the ${ }^{\circ} \mathrm{cPTIO}$ concentration did not decrease significantly (Fig. 6C). This indicates that the molecular mechanism of ${ }^{\bullet} \mathrm{cPTIO}$ reduction by $\mathrm{H}_{2} \mathrm{~S} / \mathrm{R}$-Se and $\mathrm{H}_{2} \mathrm{~S} / \mathrm{R}-\mathrm{S}$ is different. The ${ }^{\circ}$ PTIO reduction potency of the $\mathrm{H}_{2} \mathrm{~S} / \mathrm{R}$-Se mixture was several fold higher than $(\geq 5 \times)$ that of $\mathrm{H}_{2} \mathrm{~S} / \mathrm{R}-\mathrm{S}$
(Fig. 6E). The reduction of ${ }^{\circ} \mathrm{CPTIO}$ strongly depended on the $\mathrm{H}_{2} \mathrm{~S} / \mathrm{R}$-Se molar ratio: it was low at 0.5 and $1 \mathrm{H}_{2} \mathrm{~S} / \mathrm{R}$-Se molar ratios but increased significantly at 2 and 4 molar ratios (Fig. 6B and F). On the other hand, the reduction of ${ }^{\circ} \mathrm{CPTIO}$ gradually increased with the $\mathrm{H}_{2} \mathrm{~S} / \mathrm{R}$-Se molar ratio (Fig. $6 \mathrm{D}$ and $\mathrm{F}$ ). The results show that $\mathrm{H}_{2} \mathrm{~S}$ interacting with R-Se and R-S (but not with $\mathrm{R}-\mathrm{O}$ or R-OH) forms reactive products which reduce the ${ }^{\circ} \mathrm{cPTIO}$ radical. The order of potency is as follows: $\mathrm{H}_{2} \mathrm{~S} / \mathrm{R}-\mathrm{Se}>\mathrm{H}_{2} \mathrm{~S} / \mathrm{R}-\mathrm{S}$ 》 $\mathrm{H}_{2} \mathrm{~S} / \mathrm{R}-\mathrm{O} \sim \mathrm{R}-\mathrm{OH}=0$.

GSH potentiates R-Se and R-S (but not R-O or R-OH) in reducing ${ }^{\bullet}$ CPTIO. GSH is a tripeptide (glutamate-cysteine-glycine) natural antioxidant, whose intracellular concentrations are in the range of 0.5 to $10 \mathrm{mM}^{46,47}$ Therefore, we studied the effect of GSH on the reducing potency of the phthalic-anhydride derivatives. GSH $(100$ and $500 \mu \mathrm{M})$ did not reduce the ${ }^{\circ}$ CPTIO $(100 \mu \mathrm{M})$ radical alone (Fig. 7), as observed in our previous study. ${ }^{42}$ However, the GSH/R-Se (200/50 and 500/50 $\mu \mathrm{M} / \mu \mathrm{M})$ and GSH/ R-S $(200 / 50$ and $500 / 50 \mu \mathrm{M} / \mu \mathrm{M})$ mixtures significantly reduced ${ }^{\circ}$ CPTIO (Fig. 7). The kinetics of ${ }^{\circ}$ cPTIO reduction by the mixtures were different for R-Se and R-S. In the case of R-S, it was an exponential decay, but in the case of R-Se an induction period

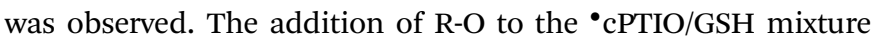
did not cause ${ }^{\bullet} \mathrm{cPTIO}$ reduction (Fig. 7). The results indicate that the reducing potency of GSH is significantly enhanced upon its interaction with R-Se and R-S. In control experiments, R-O and phthalic acid did not reduce ${ }^{\circ}$ CPTIO themselves, nor in the presence of $500 \mu \mathrm{M}$ GSH (Fig. 7). This indicates that the presence 


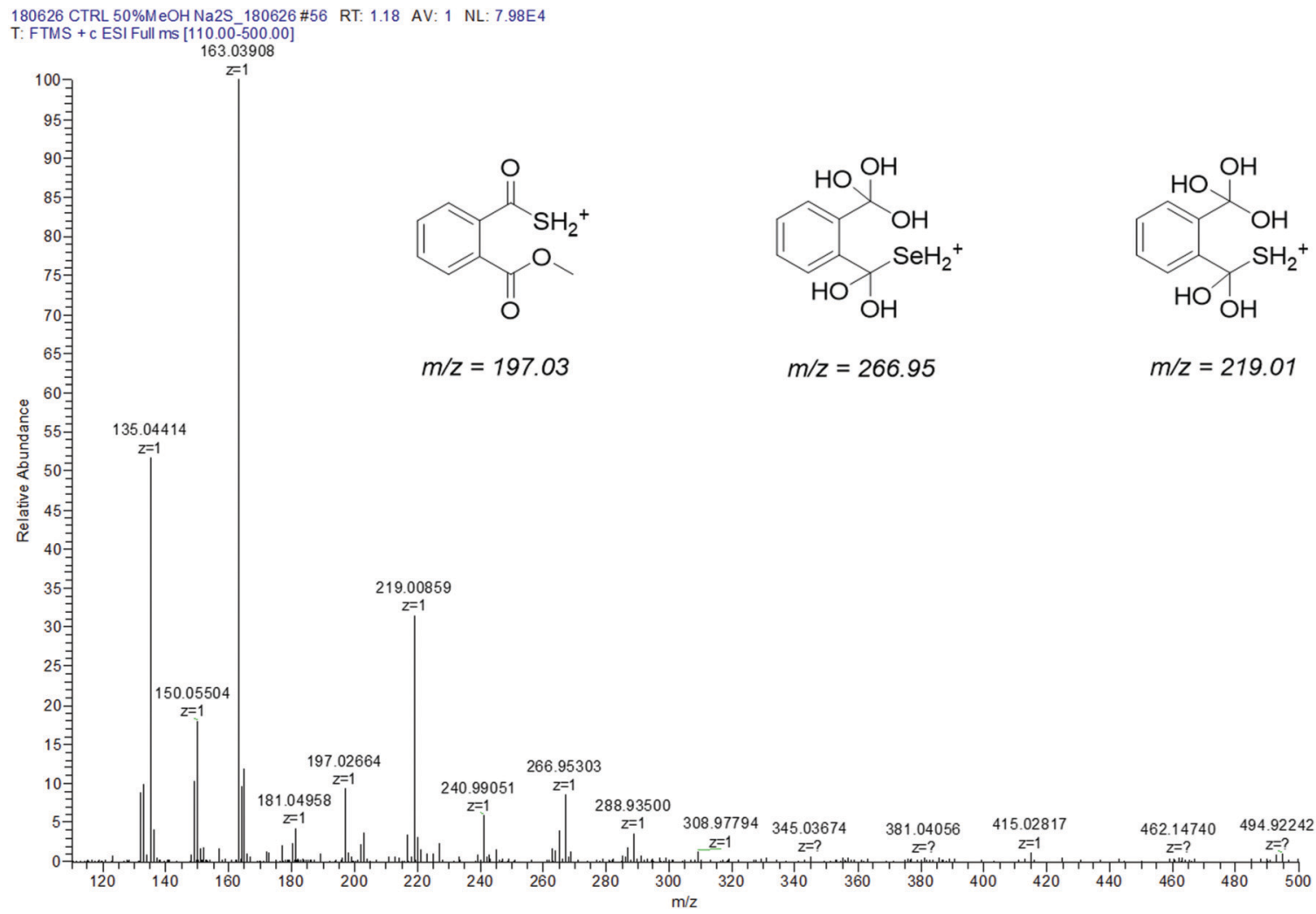

Fig. 4 Experimental ESI-MS spectrum of R-Se $+\mathrm{Na}_{2} \mathrm{~S}$ in $50 \%$ methanol/ $\mathrm{H}_{2} \mathrm{O}$. Inset: Structures suggested to explain the differential peaks with respect to the R-Se ESI-MS spectrum.
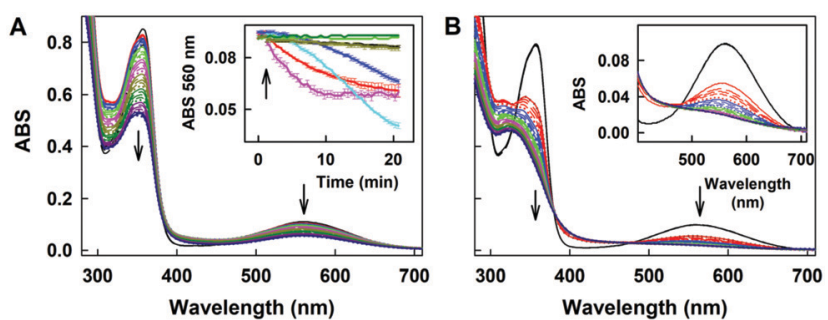

Fig. 5 Reduction of ${ }^{\mathrm{C} P T I O}$ by $\mathrm{H}_{2} \mathrm{~S}, \mathrm{R}-\mathrm{Se}, \mathrm{R}-\mathrm{S}$, RO and the R-Se/ $\mathrm{H}_{2} \mathrm{~S}$ mixture. (A) Time resolved UV-vis spectra of $100 \mu \mathrm{M} \cdot{ }^{\mathrm{C} P T I O}$ after addition of $100 \mu \mathrm{M}$ R-S. Spectra were recorded every $30 \mathrm{~s}$ for $20 \mathrm{~min}$. The first spectrum was recorded $15 \mathrm{~s}$ after R-S addition. Arrows indicate the decrease of $A B S$ at 356 and $560 \mathrm{~nm}$. Inset: Kinetics of changes in absorbance at $560 \mathrm{~nm}$ of $100 \mu \mathrm{M} \cdot \mathrm{CPTIO}$ after addition (indicated by an arrow) of: $100 \mu \mathrm{M}$ $\mathrm{H}_{2} \mathrm{~S}$ (black); 50 and $100 \mu \mathrm{M}$ R-Se (red and pink); 50 and $100 \mu \mathrm{M} \mathrm{R}-\mathrm{S}$ (blue and cyan); 50 and $100 \mu \mathrm{M} \mathrm{R}-\mathrm{O}$ (green and dark green) and a mixture of $100 \mu \mathrm{M} \mathrm{H}_{2} \mathrm{~S}$ with $100 \mu \mathrm{M} \mathrm{R}-\mathrm{O}$ (dark yellow). Means $\pm \mathrm{SEM}, n=2-4$. (B) Time resolved UV-vis spectra of the interaction of $100 \mu \mathrm{M} \cdot \mathrm{CPTIO}$ with $100 \mu \mathrm{M}$ $\mathrm{H}_{2} \mathrm{~S}$ (3 times repeated every $30 \mathrm{~s}$, black) and subsequent addition of $12.5 \mu \mathrm{M}$ $\mathrm{R}-\mathrm{Se}$. Spectra were recorded every $30 \mathrm{~s}$ for $20 \mathrm{~min}$, the first spectrum, indicated by the red line, was measured $15 \mathrm{~s}$ after addition of R-Se. Inset: Details of the time resolved spectra of the ${ }^{\circ} \mathrm{CPTIO} / \mathrm{H}_{2} \mathrm{~S}(100 / 100 \mu \mathrm{M} / \mu \mathrm{M})$ interaction before (black) and after addition of R-Se $(12.5 \mu \mathrm{M}$, the first spectrum is indicated by the solid red line, which is followed each $30 \mathrm{~s}$ by: long dashed red, medium dashed red, short dashed red, dotted red, solid blue, long dashed blue, medium dashed blue, etc.).

of Se and $\mathrm{S}$ in phthalic anhydride derivatives after interaction with $\mathrm{H}_{2} \mathrm{~S}$ and GSH is responsible for the reduction of ${ }^{\bullet} \mathrm{cPTIO}$.
$\mathrm{H}_{2} \mathrm{~S}$ and GSH interacting with $\mathrm{Na}_{2} \mathrm{Se}$-derivatives reduce -cPTIO. ESI-MS experiments (Fig. 3 and 4) show that $\mathrm{H}_{2} \mathrm{~S}$ interacts with $\mathrm{R}$-Se (and its derivatives). We observed that the $\mathrm{H}_{2} \mathrm{~S} / \mathrm{R}$-Se mixture, but not the $\mathrm{H}_{2} \mathrm{~S} / \mathrm{R}-\mathrm{O}$ or $\mathrm{H}_{2} \mathrm{~S} /$ phthalic acid mixtures, reduced ${ }^{-}$CPTIO (Fig. 6). Based on these data, we suppose that the intermediates and/or products of the $\mathrm{H}_{2} \mathrm{~S}$ interaction with Se (released from R-Se) and/or with R-Se derivatives are responsible for ${ }^{\bullet} \mathrm{CPTIO}$ reduction. To confirm this, we studied the interaction of $\mathrm{H}_{2} \mathrm{~S}$ and GSH with Se derivatives using $\mathrm{Na}_{2} \mathrm{Se}$. The UV-vis spectra of freshly prepared $100 \mu \mathrm{M} \mathrm{Na} \mathrm{N}_{2} \mathrm{Se}$ changed gradually for $20 \mathrm{~min}$ (Fig. 8A), which could be an indication of a potential slow unspecific interaction with any of the compounds present in the solution, such as diethylenetriaminepentaacetic acid (DTPA), sodium phosphate, the solvent (water) or most probably with oxygen, which acts as an oxidant. The UV-vis spectra of $\mathrm{H}_{2} \mathrm{~S} / \mathrm{Na}_{2} \mathrm{Se}(100 / 100 \mu \mathrm{M} / \mu \mathrm{M})$ also changed gradually for $20 \mathrm{~min}$ (Fig. 8B). Since the time dependence of the UV-vis spectra of $\mathrm{Na}_{2} \mathrm{Se}$ (Fig. $8 \mathrm{~A}$ ) and the $\mathrm{Na}_{2} \mathrm{Se} / \mathrm{H}_{2} \mathrm{~S}$ mixture (Fig. 8B) were different (marked by arrows), we confirm the interaction of $\mathrm{H}_{2} \mathrm{~S}$ with $\mathrm{Na}_{2} \mathrm{Se}$ derivatives.

The time resolved UV-vis spectra of ${ }^{\circ} \mathrm{PTIO} / \mathrm{Na}_{2} \mathrm{Se}(100 /$ $100 \mu \mathrm{M} / \mu \mathrm{M}$ ) show no ${ }^{\circ} \mathrm{cPTIO}$ reduction by $\mathrm{Na}_{2} \mathrm{Se}$ alone, since ABS at $356 \mathrm{~nm}$ (marked by an arrow) did not decrease over the time (Fig. $8 \mathrm{C}$ and F), nor ABS at $560 \mathrm{~nm}$ (Fig. 8C, inset). $\mathrm{H}_{2} \mathrm{~S}(100 \mu \mathrm{M})$ or GSH $(500 \mu \mathrm{M})$ had only minor effects $(\leq 7 \%)$ on their own in terms of ${ }^{\circ}$ PTIO $(100 \mu \mathrm{M})$ reduction within $20 \mathrm{~min}$. However, addition of freshly prepared $\mathrm{Na}_{2} \mathrm{Se}(100 \mu \mathrm{M})$ to the $\mathrm{H}_{2} \mathrm{~S} /{ }^{\circ}$ cPTIO 

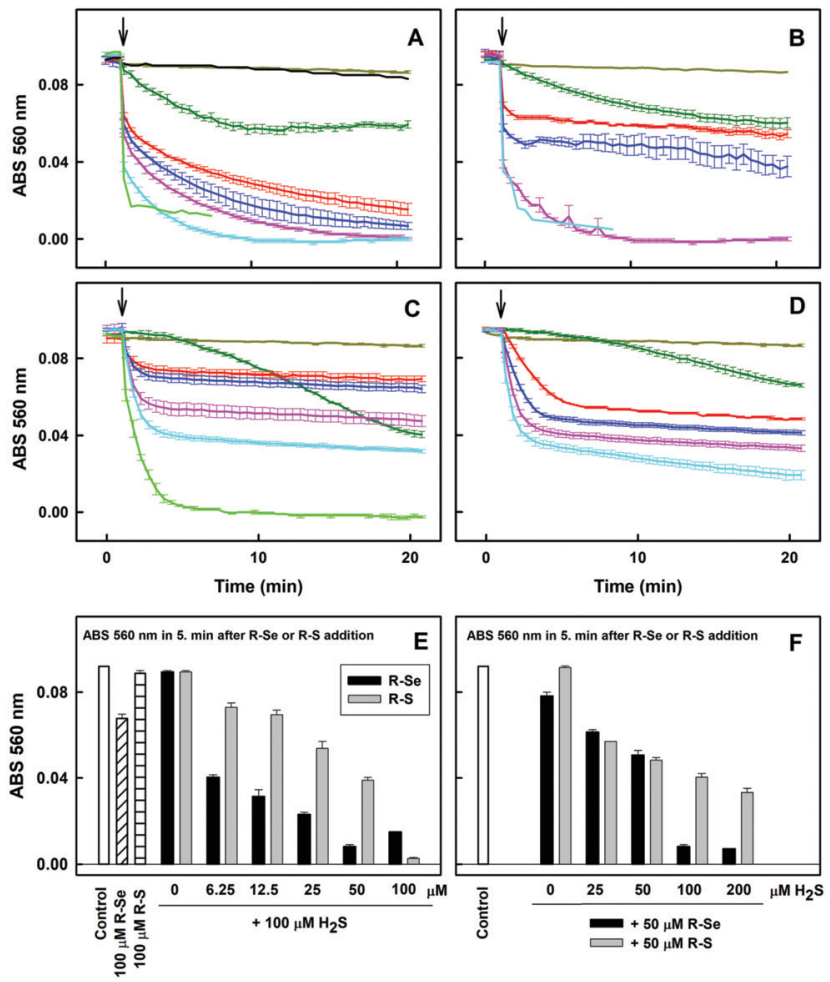

Fig. 6 The effect of $\mathrm{R}-\mathrm{Se}$ and $\mathrm{R}-\mathrm{S}$ on the kinetics of ${ }^{\circ} \mathrm{CPTIO}$ reduction in the absence and presence of $\mathrm{H}_{2} \mathrm{~S}$. (A) The effect of R-Se and R-OH on the time-dependent reduction of ${ }^{\circ} \mathrm{CPTIO} / \mathrm{H}_{2} \mathrm{~S}$. Kinetics of changes in absorbance at $560 \mathrm{~nm}$ of $100 \mu \mathrm{M}{ }^{\circ} \mathrm{CPTIO}$ after addition (indicated by an arrow) of $100 \mu \mathrm{M}$ R-Se alone (dark green) and compared to the addition of 0 (dark yellow), 6.25 (red), 12.5 (blue), 25 (pink), 50 (cyan) and $100 \mu \mathrm{M}$ (green) R-Se to ${ }^{\circ} \mathrm{CPTIO} / \mathrm{H}_{2} \mathrm{~S}(100 / 100 \mu \mathrm{M} / \mu \mathrm{M})$. $50 \mu \mathrm{M} \mathrm{R}-\mathrm{OH}$ added to ${ }^{\circ} \mathrm{CPTIO} / \mathrm{H}_{2} \mathrm{~S}$ (black; $100 / 100 \mu \mathrm{M} / \mu \mathrm{M}$ ). Data were collected from UV-vis spectra every $30 \mathrm{~s}$ for $20 \mathrm{~min}$. (B) The effect of $\mathrm{H}_{2} \mathrm{~S}$ on the kinetics of reduction of ${ }^{\bullet} \mathrm{CPTIO}$ in the presence of R-Se. Kinetics of changes in absorbance at $560 \mathrm{~nm}$ of $100 \mu \mathrm{M} \cdot \mathrm{CPTIO}$ after addition (indicated by an arrow) of $100 \mu \mathrm{M} \mathrm{H}_{2} \mathrm{~S}$ alone (dark yellow) and after addition of $50 \mu \mathrm{M}$ R-Se to $0 \mu \mathrm{M}$ (dark green), $25 \mu \mathrm{M}$ (red), $50 \mu \mathrm{M}$ (blue), $100 \mu \mathrm{M}$ (pink) and $200 \mu \mathrm{M} \mathrm{H}_{2} \mathrm{~S}$ (cyan). (C) The effect of $\mathrm{R}-\mathrm{S}$ on the kinetics of ${ }^{\circ} \mathrm{CPTIO}$ reduction in the presence of $\mathrm{H}_{2} \mathrm{~S}$. Kinetics of changes in absorbance at $560 \mathrm{~nm}$ of $100 \mu \mathrm{M}{ }^{\circ} \mathrm{CPTIO}$ after addition (indicated by an arrow) of $100 \mu \mathrm{M}$ R-S alone (dark green) and compared to the addition of 0 (dark yellow), 6.25 (red), 12.5 (blue), 25 (pink), 50 (cyan) and $100 \mu \mathrm{M}$ (green) R-S to ${ }^{\circ} \mathrm{CPTIO} / \mathrm{H}_{2} \mathrm{~S}(100 / 100 \mu \mathrm{M} / \mu \mathrm{M})$. (D) The effect of $\mathrm{H}_{2} \mathrm{~S}$ on the kinetics of ${ }^{\circ} \mathrm{CPTIO}$ reduction in the presence of R-S. Kinetics of changes in absorbance at $560 \mathrm{~nm}$ of $100 \mu \mathrm{M} \cdot \mathrm{CPTIO}$ after addition (indicated by an arrow) of $100 \mu \mathrm{M} \mathrm{H} \mathrm{H}_{2} \mathrm{~S}$ alone (dark yellow) and after

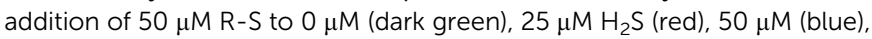

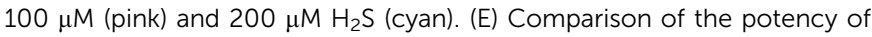
$\mathrm{R}$-Se and R-S to reduce ${ }^{-} \mathrm{CPTIO}$ in the presence of $\mathrm{H}_{2} \mathrm{~S}$. Reduction of -CPTIO $(100 \mu \mathrm{M})$ by R-Se and R-S $(100 \mu \mathrm{M})$ and reduction of ${ }^{\circ} \mathrm{CPTIO}$ in the presence of $\mathrm{H}_{2} \mathrm{~S}(100 \mu \mathrm{M})$ after addition of $0,6.12,12.5,25,50$ and $100 \mu \mathrm{M}$ $\mathrm{R}$-Se or R-S. The changes in absorbance at $560 \mathrm{~nm}$ of $100 \mu \mathrm{M} \cdot \mathrm{CPTIO}$ were taken from ( $\mathrm{A}$ and $\mathrm{C}$ ) at the 5th min after the addition of the compound. (F) Comparison of the potency of R-Se and R-S to reduce ${ }^{\circ} \mathrm{CPTIO}$ in the presence of different concentrations of $\mathrm{H}_{2} \mathrm{~S}$. Reduction of ${ }^{\circ} \mathrm{CPTIO}(100 \mu \mathrm{M})$ by R-Se and R-S $(50 \mu \mathrm{M})$ in the presence of $0,25,50,100$ and $200 \mu \mathrm{M} \mathrm{H}_{2} \mathrm{~S}$. The changes in absorbance at $560 \mathrm{~nm}$ of $100 \mu \mathrm{M} \cdot \mathrm{cPTIO}$ were taken from $(B$ and $D)$ at the 5 th min after the addition of the compound. Mean $\pm S E M$, $n=2-4$.

$(100 / 100 \mu \mathrm{M} / \mu \mathrm{M})$ or $\mathrm{GSH} /{ }^{\bullet} \mathrm{cPTIO}(500 / 100 \mu \mathrm{M} / \mu \mathrm{M})$ mixture reduced ${ }^{\bullet} \mathrm{cPTIO}$ (decreased ABS at 356 and $560 \mathrm{~nm}$ ) in $<1 \mathrm{~min}$

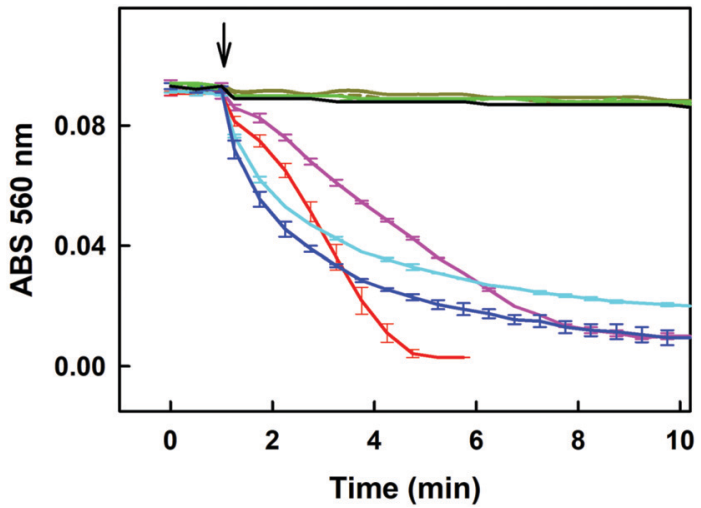

Fig. 7 Effect of GSH on the ${ }^{\circ} \mathrm{CPTIO}$ reduction kinetics in the presence of $\mathrm{R}-\mathrm{Se}, \mathrm{R}-\mathrm{S}, \mathrm{R}-\mathrm{O}$ and $\mathrm{R}-\mathrm{OH}$. Kinetics of the changes in absorbance at $560 \mathrm{~nm}$ of $100 \mu \mathrm{M} \cdot \mathrm{CPTIO}$ after addition (indicated by an arrow) of 100 (dashed dark-yellow) and $500 \mu \mathrm{M} \mathrm{GSH}$ (solid dark yellow); after addition of $50 \mu \mathrm{M}$ R-Se to ${ }^{\circ} \mathrm{CPTIO} / \mathrm{GSH}\left(100 / 200 \mu \mathrm{M} / \mu \mathrm{M}\right.$; pink), and to ${ }^{\circ} \mathrm{CPTIO} / \mathrm{GSH}$ $\left(100 / 500 \mu \mathrm{M} / \mu \mathrm{M}\right.$; red); after addition of $50 \mu \mathrm{M}$ R-S to ${ }^{\circ} \mathrm{CPTIO} / \mathrm{GSH}$ (100/ $200 \mu \mathrm{M} / \mu \mathrm{M}$; cyan), and to ${ }^{\mathrm{CPTIO} / \mathrm{GSH}}(100 / 500 \mu \mathrm{M} / \mu \mathrm{M}$; blue); after addition of $50 \mu \mathrm{M}$ R-O to ${ }^{\circ} \mathrm{CPTIO} / \mathrm{GSH}(100 / 200 \mu \mathrm{M} / \mu \mathrm{M}$; dashed green), and to ${ }^{\circ} \mathrm{CPTIO} / \mathrm{GSH}(100 / 500 \mu \mathrm{M} / \mu \mathrm{M}$; solid green); and after addition of $50 \mu \mathrm{M} \mathrm{R}-\mathrm{OH}$ to ${ }^{\circ} \mathrm{CPTIO} / \mathrm{GSH}(100 / 500 \mu \mathrm{M} / \mu \mathrm{M}$; black). Mean $\pm \mathrm{SEM}, n=2-3$.

(Fig. 8D-F), indicating formation of reducing species during the interaction of $\mathrm{Na}_{2}$ Se-derivatives with $\mathrm{H}_{2} \mathrm{~S}$ and $\mathrm{GSH}$ which reduce the ${ }^{\bullet}$ cPTIO radical. The results support the suggestion that $\mathrm{H}_{2} \mathrm{~S}$ and GSH significantly potentiated the reducing properties of Se derivatives which are released from R-Se.

\section{Discussion of the reduction of ${ }^{\bullet}$ CPTIO by phthalic-anhydride derivatives and $\mathrm{H}_{2} \mathrm{~S}$}

Regarding the reduction of the ${ }^{\circ}$ PTIO radical, R-S and R-Se showed a higher capacity to reduce this radical in comparison with $\mathrm{H}_{2} \mathrm{~S}$. But $\mathrm{H}_{2} \mathrm{~S}$ was most effective in the reduction of the - cPTIO free radical compared to phthalic acid and phthalic anhydride. This fact suggests that the mechanism that explains this reduction must be related to a characteristic reaction of R-S and R-Se that is not demonstrated by $\mathrm{R}-\mathrm{O}$ or by $\mathrm{R}-\mathrm{OH}$. A potential candidate for the reaction that led to this observation could be then the release of sulfide or selenide anions, respectively, as the release of $\mathrm{O}^{2-}$ is non-existent. All sulfide or selenide anions would probably be partially protonated in buffered solution. $\mathrm{H}_{2} \mathrm{~S}$ is produced endogenously and exerts relevant biological effects and functions. It can be found in tissue cells in non-negligible physiological concentrations that reach even higher than $1 \mu \mathrm{M} .^{55}$ Besides, its local space-time concentration in microenvironments can be even several times higher. This fact indicates that the $\mathrm{H}_{2} \mathrm{~S}$ / $\mathrm{R}$-Se interaction may be involved also in the biological activities of R-Se. Thus, we have evaluated how it interacts with these chalcogen phthalic derivatives. The results were in line with the previous observations and supported our hypothesis of the $\mathrm{S}^{2-}$ and $\mathrm{Se}^{2-}$ release: the addition of $\mathrm{H}_{2} \mathrm{~S}$ to $\mathrm{R}-\mathrm{S}$ and R-Se potentiated the above mentioned reduction of the ${ }^{-}$cPTIO radical. It is noteworthy that the addition of $\mathrm{H}_{2} \mathrm{~S}$ promoted the reduction exerted by R-Se more than the one induced by R-S. In contrast, the addition of $\mathrm{H}_{2} \mathrm{~S}$ to $\mathrm{R}-\mathrm{O}$ and $\mathrm{R}-\mathrm{OH}$ did not exert any effect. Interestingly, the 

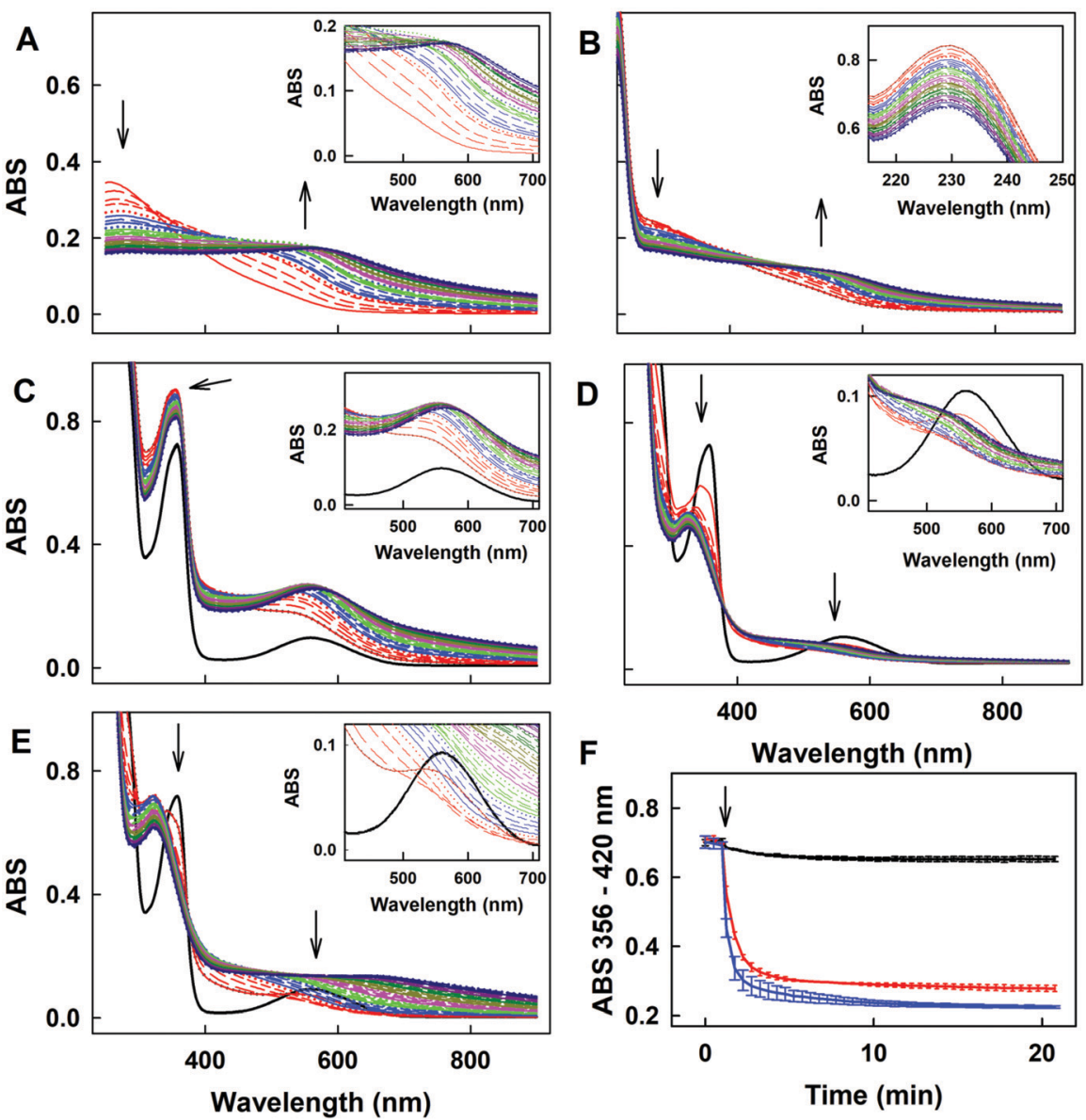

Fig. $8 \mathrm{UV}$-vis spectra of the interaction of $\mathrm{Na}_{2} \mathrm{Se}$ with ${ }^{\circ} \mathrm{CPTIO} / \mathrm{H}_{2} \mathrm{~S}$ and ${ }^{\circ} \mathrm{CPTIO} / \mathrm{GSH}$. (A) Time resolved UV-vis spectra of $100 \mu \mathrm{M} \mathrm{Na} 2 \mathrm{Se}$ in $100 \mathrm{mM}$ sodium phosphate, $100 \mu \mathrm{M}$ DTPA, pH 7.4 buffer at $37{ }^{\circ} \mathrm{C}$. Spectra were collected every $30 \mathrm{~s}$ for $20 \mathrm{~min}$, the first spectrum was measured $15 \mathrm{~s}$ after addition of $\mathrm{Na}_{2} \mathrm{Se}$. Insets are details. The first spectrum is indicated by the solid red line, which is followed each $30 \mathrm{~s}$ by: long dashed red, medium dashed red, short dashed red, dotted red, solid blue, long dashed blue, medium dashed blue, etc. (B) Time resolved UV-vis spectra of the interaction of $100 \mu \mathrm{M} \mathrm{Na} \mathrm{S}_{2} \mathrm{Se}$ with $100 \mu \mathrm{M} \mathrm{H} \mathrm{H}_{2} \mathrm{~S}$. Spectra were collected every $30 \mathrm{~s}$ for $20 \mathrm{~min}$, the first spectrum, indicated by the solid red line, was measured $15 \mathrm{~s}$ after addition of $\mathrm{Na}_{2} \mathrm{Se}$ to $\mathrm{H}_{2} \mathrm{~S}$. Inset: Details of the time resolved spectra of $\mathrm{HS}^{-}$, peak at $230 \mathrm{~nm}$. (C) Time resolved UV-vis spectra of the interaction of $100 \mu \mathrm{M} \cdot{ }^{\mathrm{CPTIO}}$ with $100 \mu \mathrm{M} \mathrm{Na} \mathrm{Se}$ $\left({ }^{\circ} \mathrm{CPTIO}-3\right.$ times repeated every $30 \mathrm{~s}$, black) and subsequent addition of $100 \mu \mathrm{M} \mathrm{Na} \mathrm{a}_{2}$ Se. Spectra were collected every $30 \mathrm{~s}$ for $20 \mathrm{~min}$, the first spectrum, indicated by the solid red line, was measured $15 \mathrm{~s}$ after addition of $\mathrm{Na}_{2} \mathrm{Se}$. The arrow indicates ABS at $356 \mathrm{~nm}$. Inset: Details of the time resolved spectra of the ${ }^{\circ} \mathrm{CPTIO} / \mathrm{Na}_{2} \mathrm{Se}(100 / 100 \mu \mathrm{M} / \mu \mathrm{M})$ interaction before (black) and after addition of $\mathrm{Na}_{2} \mathrm{Se}(100 \mu \mathrm{M})$. (D) Time resolved UV-vis spectra of the interaction of $\mathrm{Na}_{2} \mathrm{Se}$ with ${ }^{\circ} \mathrm{CPTIO} / \mathrm{H}_{2} \mathrm{~S}$. Control ${ }^{\circ} \mathrm{CPTIO} / \mathrm{H}_{2} \mathrm{~S}\left(100 / 100 \mu \mathrm{M} / \mu \mathrm{M} ; 3\right.$ times repeated every $30 \mathrm{~s}$, black), and subsequent addition of $100 \mu \mathrm{M} \mathrm{Na}{ }_{2} \mathrm{Se}$. Spectra were collected every $30 \mathrm{~s}$ for $20 \mathrm{~min}$, the first spectrum, indicated by the red line, was measured $15 \mathrm{~s}$ after addition of $\mathrm{Na}_{2} \mathrm{Se}$. The arrows indicate the decrease of $\mathrm{ABS}$ at 356 and $560 \mathrm{~nm}$. Inset: Details of the time resolved spectra of the ${ }^{\circ} \mathrm{CPTIO} / \mathrm{H}_{2} \mathrm{~S}(100 / 100 \mu \mathrm{M} / \mu \mathrm{M})$ interaction before (black) and after addition of $\mathrm{Na} \mathrm{S}_{2} \mathrm{Se}$ $(100 \mu \mathrm{M})$. (E) Time resolved UV-vis spectra of the interaction of $\mathrm{Na}_{2} \mathrm{Se}$ with ${ }^{\circ} \mathrm{CPTIO} / \mathrm{GSH}$. Control ${ }^{\circ} \mathrm{CPTIO} / \mathrm{GSH}(100 / 500 \mu \mathrm{M} / \mu \mathrm{M} ; 3$ times repeated every $30 \mathrm{~s}$, black), and subsequent addition of $100 \mu \mathrm{M} \mathrm{Na} 2$ Se. Spectra were collected every $30 \mathrm{~s}$ for $20 \mathrm{~min}$, the first spectrum, indicated by the solid red line, was measured $15 \mathrm{~s}$ after addition of $\mathrm{Na}_{2} \mathrm{Se}$. The arrows indicate the decrease of ABS at 356 and $560 \mathrm{~nm}$. Inset: Details of the time resolved spectra of the ${ }^{\circ} \mathrm{CPTIO} /$ GSH $(100 / 500 \mu \mathrm{M} / \mu \mathrm{M})$ interaction before (black) and after addition of $\mathrm{Na}_{2} \mathrm{Se}(100 \mu \mathrm{M})$. (F) Kinetics of the interaction of $\mathrm{Na}_{2} \mathrm{Se}(100 \mu \mathrm{M}$, marked by an arrow) with ${ }^{\circ} \mathrm{CPTIO}\left(100 \mu \mathrm{M}\right.$, black), ${ }^{\circ} \mathrm{CPTIO} / \mathrm{H}_{2} \mathrm{~S}\left(100 / 100 \mu \mathrm{M} / \mu \mathrm{M}\right.$, blue) and ${ }^{\circ} \mathrm{CPTIO} / \mathrm{GSH}(100 / 500 \mu \mathrm{M} / \mu \mathrm{M}$, red) monitored as changes of ABS at $356 \mathrm{~nm}$ with correction to $420 \mathrm{~nm}$; mean $\pm \mathrm{SEM}, n=2-3$.

interaction of $\mathrm{H}_{2} \mathrm{~S}$ with R-Se is dependent on the molar ratio between the Se analogue and $\mathrm{H}_{2} \mathrm{~S}$ : when R-Se is predominant or when both are equimolar, a low reduction is observed. However, when the molar ratio $\mathrm{H}_{2} \mathrm{~S} / \mathrm{R}$-Se is 2 to 4 , the detected reduction increased significantly. This fact could suggest that a reaction between $\mathrm{H}_{2} \mathrm{~S}$ and R-Se takes place and that the concentration of the first potentiates this reaction, although the R-Se is also crucial as its replacement by R-S reduced the observed potentiation effect.

Another sulfur-containing biogenic compound with crucial functions is GSH, which can reach intracellular concentrations in the range $0.5-10 \mathrm{mM}$. Thus, we have also evaluated its interaction with the phthalic anhydride derivatives, as this interaction may be involved in the R-Se biological effects. And effectively similar results of potentiation of the R-Se and R-S ability to reduce the ${ }^{\bullet}$ cPTIO radical were obtained, being then again more significant for R-Se than for R-S. The phthalic anhydride derivatives could interact also with other components of the cellular thiolstat, or even with other different enzymes. For example, they could be activated through different cellular enzymes, such as disulfide reductases and esterases. However, further research 
needs to be conducted in future work to confirm this extent. In this study we have selected $\mathrm{GSH}$ and $\mathrm{H}_{2} \mathrm{~S}$ as representative compounds of the sulfur containing components involved in the redox thiolstat. The enhancement of the R-Se activity with respect to the potentiation observed for R-S by the two thiols evaluated $\left(\mathrm{H}_{2} \mathrm{~S}\right.$ and $\left.\mathrm{GSH}\right)$ was observed and therefore we tested how $\mathrm{H}_{2} \mathrm{~S}$ and $\mathrm{GSH}$ reduced the ${ }^{\bullet}$ cPTIO radical in the absence of R-Se, finding that in this case there was no interaction. This confirms the key role of R-Se in this interaction, and the requirement of having both $\mathrm{Se}$ and $\mathrm{S}$ species to have a more effective interaction.

\section{Cleavage of pDNA}

We wanted to ascertain whether the products of the $\mathrm{H}_{2} \mathrm{~S} / \mathrm{R}$-Se and/or GSH/R-Se interaction can directly attack pDNA without the contribution of other (unknown) biologically important molecules and/or pathways. Briefly, the pDNA cleavage assay can detect any activity that attacks and disrupts the sugarphosphate backbone of DNA (e.g., reactive oxygen species, free radicals etc.).

$\mathrm{H}_{2} \mathrm{~S}$ and GSH interacting with phthalic-anhydride derivatives cleave pDNA. To compare the pDNA cleavage activity caused or mediated by the phthalic-anhydride derivatives, increasing concentrations of these compounds were incubated with pDNA in vitro and the resulting reaction mixtures were subjected to electrophoretic separation to resolve the individual pDNA forms. $\mathrm{R}-\mathrm{S}$, R-O or R-OH had only minor effects on pDNA cleavage. In contrast, R-Se cleaved pDNA in a concentration-dependent manner at concentrations $\geq 50 \mu \mathrm{M}$ (Fig. 9).

Notably, $\mathrm{H}_{2} \mathrm{~S}$ modulated the pDNA cleavage activity of the anhydride derivatives depending on the $\mathrm{H}_{2}$ S/anhydride derivative molar ratio. In the presence of $50 \mu \mathrm{M}$ of R-Se, increasing concentrations of $\mathrm{H}_{2} \mathrm{~S}$ caused bell-shaped effects with a maximum level being reached at 100/50 and $200 / 50 \mu \mathrm{M} / \mu \mathrm{M} \mathrm{H_{2 }}$ S/R-Se molar ratios. The effect of $50 \mu \mathrm{M}$ of R-S, R-O and R-OH increased with increasing $\mathrm{H}_{2} \mathrm{~S}$ concentrations (Fig. 10A). In the presence of $100 \mu \mathrm{M} \mathrm{H} \mathrm{H}_{2} \mathrm{~S}$, the pDNA cleavage activity of R-Se was several

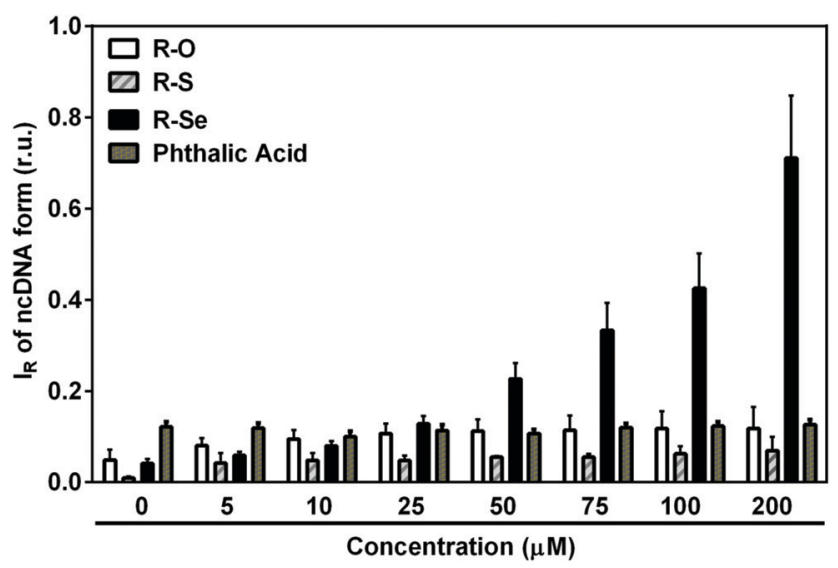

Fig. 9 The effect of anhydride-derivatives on pDNA integrity. Increasing concentrations of R-Se, R-S, R-O or phthalic acid were incubated with pDNA for $30 \mathrm{~min}$ at $37{ }^{\circ} \mathrm{C}$ and the resulting pDNA forms were resolved using agarose gel electrophoresis. Mean $\pm \mathrm{SEM}, n=3$.
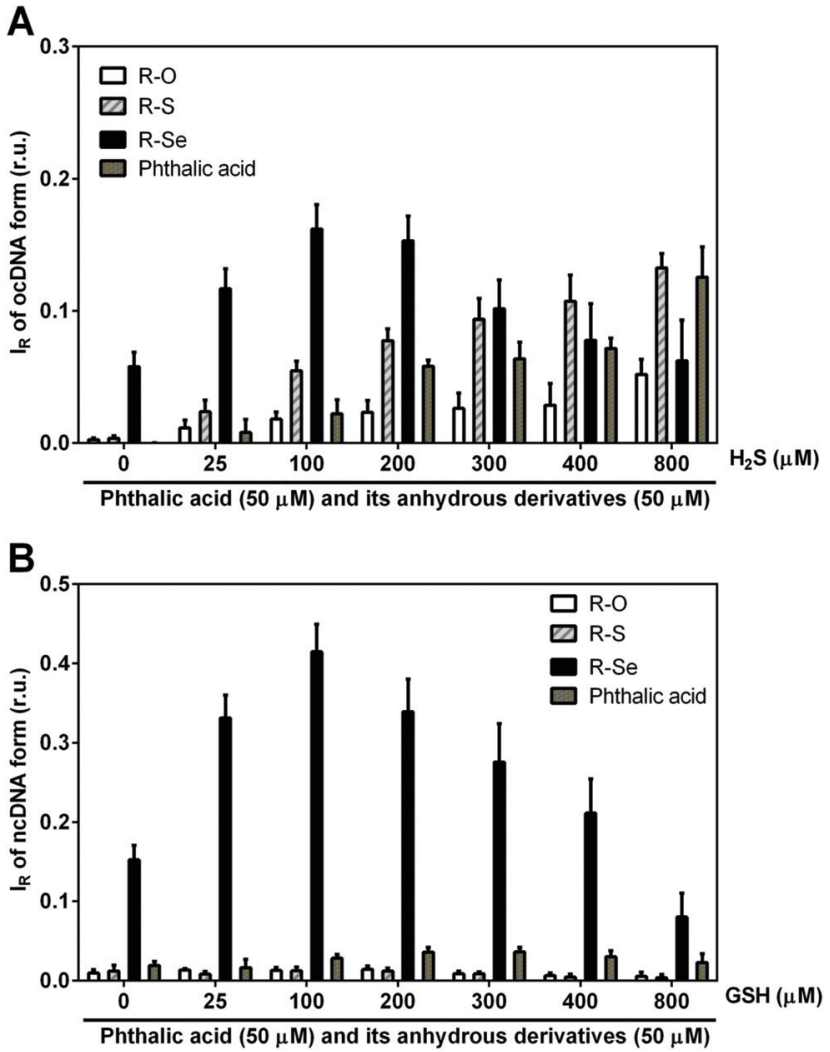

Fig. 10 The effect of increasing concentrations of $\mathrm{H}_{2} \mathrm{~S}(\mathrm{~A})$ and $\mathrm{GSH}(\mathrm{B})$ on the pDNA integrity in the presence of the anhydride-derivatives R-Se, R-S, $\mathrm{R}-\mathrm{O}$ and $\mathrm{R}-\mathrm{OH}$ at $50 \mu \mathrm{M}$ concentrations. Mean $\pm \mathrm{SEM}, n=3-5$.

times higher in comparison to R-S, R-O or R-OH. Also GSH modulated the pDNA cleavage activity of the anhydride derivatives. In the presence of $50 \mu \mathrm{M}$ R-Se, increasing concentrations of GSH mediated bell-shaped effects with a maximum level being seen at a $100 / 50 \mu \mathrm{M} / \mu \mathrm{M}$ GSH/R-Se molar ratio. In the presence of $50 \mu \mathrm{M}$ R-S, R-O or R-OH, increasing concentrations of GSH had no effects on the pDNA cleavage (Fig. 10B).

As we detected relatively similar pDNA cleavage efficiencies at $1: 1$ and $1: 3$ molar ratios of $\mathrm{R}-\mathrm{Se}: \mathrm{H}_{2} \mathrm{~S}$, we checked whether there was a difference in kinetics between the two reactions. However, the two reactions displayed the same (linear) timedependent pDNA cleavage efficiency, suggesting that within a $1: 1-1: 3$ (R-Se : $\left.\mathrm{H}_{2} \mathrm{~S}\right)$ molar ratio window, $\mathrm{R}-\mathrm{Se}$ is a rate-limiting factor in the reaction (Fig. 11).

Summing up, we have observed that R-S, R-O and R-OH only exerted limited pDNA cleavage activity, whereas this activity increased significantly when R-Se was employed in a concentration-dependent manner. Interestingly, the addition of $\mathrm{H}_{2} \mathrm{~S}$ and GSH modulated strongly this pDNA cleavage action, and showed a bell-shaped effect, suggesting that the kinetics may be a rate-limiting factor in this action. In this case, the pDNA cleavage exerted by the remaining phthalic derivatives tested in the presence of $\mathrm{H}_{2} \mathrm{~S}$ increased in a concentration dependent manner with $\mathrm{H}_{2} \mathrm{~S}$, which may be caused by the $\mathrm{H}_{2} \mathrm{~S}$-related pDNA cleavage effect. Thus, it is noteworthy that the pDNA cleavage in the absence of $\mathrm{H}_{2} \mathrm{~S}$ and the bell-shaped modulation in the presence of $\mathrm{H}_{2} \mathrm{~S}$ and 


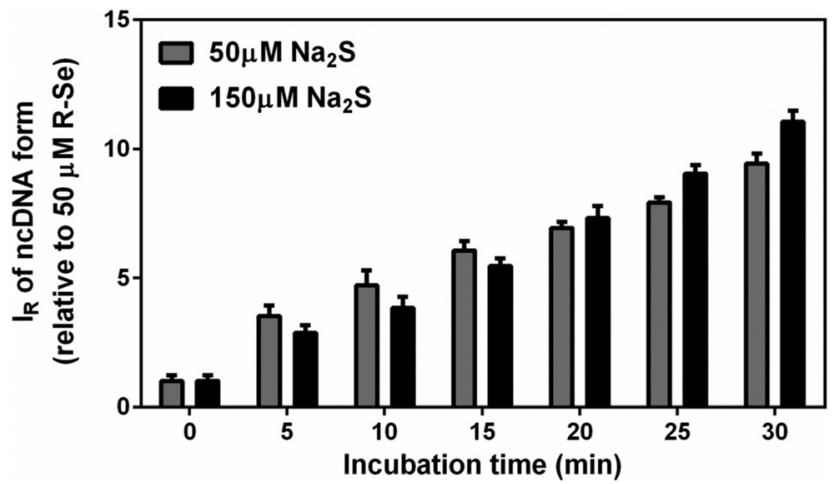

Fig. 11 Comparison of time-dependent pDNA cleavage by $\mathrm{H}_{2} \mathrm{~S} / \mathrm{R}-\mathrm{Se}$ at molar ratios $50 / 50$ and $150 / 50 \mu \mathrm{M} / \mu \mathrm{M}$. The $\mathrm{H}_{2} \mathrm{~S} / \mathrm{R}$-Se mixture was incubated with $\mathrm{pDNA}$ for the given time. $I_{R}$ of $\mathrm{nCDNA}$ was normalized relative to $50 \mu \mathrm{M}$ R-Se. Mean \pm SEM, $n=3$.

GSH are only observed when R-Se is employed, which underlines the unique redox-modulating properties of $\mathrm{R}$-Se and indicates the possibility of the formation of a S-Se intermediate when $\mathrm{H}_{2} \mathrm{~S}$ interacts with R-Se.

The ability of R-Se, R-S and R-O without and with $\mathrm{H}_{2} \mathrm{~S}$ to scavenge the $\mathrm{O}_{2}{ }^{\bullet-}$ radical or its derivatives. Since we observed that the mixture of $\mathrm{H}_{2} \mathrm{~S}$ and R-Se or R-S significantly potentiated - cPTIO reduction, it was of interest to study if the mixture can scavenge $\mathrm{O}_{2}{ }^{\bullet-}$ radicals. The EPR spin trap method based on the reaction of $\mathrm{O}_{2}{ }^{\bullet-}$ with $\mathrm{BMPO}$ to form the ${ }^{\bullet} \mathrm{BMPO}-\mathrm{OOH}$ adducts (conformer I and II) were employed. ${ }^{56}$ The $\mathrm{O}_{2}{ }^{\bullet-}$ radical anion solution (prepared by dissolving $\mathrm{KO}_{2}$ in DMSO) was diluted in phosphate buffer ( $\mathrm{pH} 7.4 ; 37^{\circ} \mathrm{C}$ ) and trapped by BMPO.

Under these conditions, the relative intensity of the ${ }^{\circ} \mathrm{BMPO}-$ $\mathrm{OOH}$ adducts decreased slowly over the time and was comparable to the values reported under physiological conditions (Fig. 12A1-A3). ${ }^{56}$ The addition of R-Se or R-O $(25 \mu \mathrm{M})$ had a minor effect on the -BMPO-OOH adducts formation, their concentration or rate of decay (Fig. 12B1-B3, D1-D3, 13A and B). In contrast, R-S (25 $\mu \mathrm{M})$ significantly decreased the quantity of the ${ }^{\circ} \mathrm{BMPO}$-adducts (Fig. 12C1-C3, 13A and $\mathrm{B}$ ) and from the decreased ratio of the •BMPO-OOH $/{ }^{\bullet} \mathrm{BMPO}$-adducts (Fig. $12 \mathrm{C}$ and D), a superposition of at least two radicals, ${ }^{\circ} \mathrm{BMPO}-\mathrm{OOH}$ and ${ }^{\circ} \mathrm{BMPO}-\mathrm{OH}$, was recognized. $\mathrm{H}_{2} \mathrm{~S}(50 \mu \mathrm{M})$ had similar effects to R-S, however its potency to decrease the quantity of the ${ }^{\bullet} \mathrm{BMPO}$-adducts and

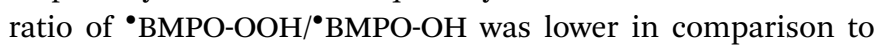
R-S (Fig. 12E1-E3 and 13).

The presence of $\mathrm{H}_{2} \mathrm{~S}(50 \mu \mathrm{M})$ in the R-Se or R-S $(25 \mu \mathrm{M})$ solution significantly decreased the quantity of the ${ }^{\bullet} \mathrm{BMPO}$-adducts (Fig. 12F1-F3, G1-G3, 13A and B) and significantly decreased the ratio of the ${ }^{\bullet} \mathrm{BMPO}-\mathrm{OOH} /{ }^{\bullet} \mathrm{BMPO}$-adducts (Fig. $13 \mathrm{C}$ and D), where a superposition of at least two radicals, ${ }^{\bullet} \mathrm{BMPO}-\mathrm{OOH}$ and ${ }^{\bullet} \mathrm{BMPO}-$ $\mathrm{OH}$, was recognized. Alternatively, a mixture of $\mathrm{H}_{2} \mathrm{~S}(50 \mu \mathrm{M})$ with R-O $(25 \mu \mathrm{M})$ caused a similar effect to $\mathrm{H}_{2} \mathrm{~S}$ alone (Fig. 12H1-H3 and 13). Based on the decreasing quantity of the ${ }^{\bullet} \mathrm{BMPO}$-adducts, we suggest that R-S, $\mathrm{H}_{2} \mathrm{~S} / \mathrm{R}-\mathrm{Se}$ and $\mathrm{H}_{2} \mathrm{~S} / \mathrm{R}-\mathrm{S}$ scavenge the ${ }^{\bullet} \mathrm{BMPO}-$ $\mathrm{OOH} / \mathrm{OH}$ adducts, which may include direct scavenging of $\mathrm{O}_{2}{ }^{\bullet-}$ or its derivatives. The decreasing ratio of the ${ }^{\bullet} \mathrm{BMPO}-\mathrm{OOH} /{ }^{\bullet} \mathrm{BMPO}-$ adducts indicates that the compounds cause the decomposition
EPR: $\mathrm{BMPO}+\mathrm{KO}_{2}$

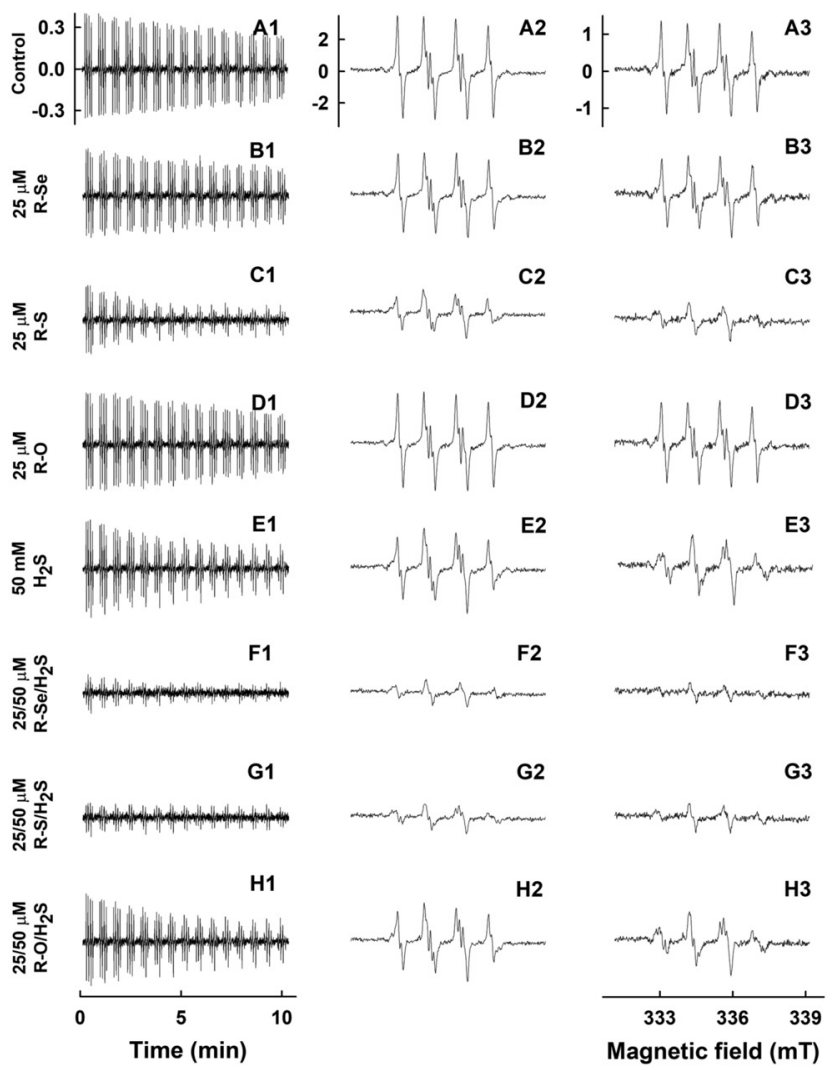

Fig. 12 EPR spectra of ${ }^{\bullet} \mathrm{BMPO}$ in the presence of $\mathrm{O}_{2}{ }^{\bullet-}$ and modulated by $\mathrm{R}-\mathrm{Se}, \mathrm{R}-\mathrm{S}$ and $\mathrm{R}-\mathrm{O}$ without and with $\mathrm{H}_{2} \mathrm{~S}$. Representative EPR spectra of the $\cdot \mathrm{BMPO}$-adducts were monitored in $10 \% \mathrm{v} / \mathrm{v}$ saturated $\mathrm{KO}_{2} / \mathrm{DMSO}$ solution in $50 \mathrm{mM}$ sodium phosphate buffer, $0.1 \mathrm{mM}$ DTPA, $\mathrm{pH} 7.4$, $37{ }^{\circ} \mathrm{C}$ in the presence of the studied species investigated and $20 \mathrm{mM}$ BMPO. Sets of individual EPR spectra of the $B$ BMPO-adducts monitored with 15 sequential scans, each $42 \mathrm{~s}(\mathrm{~A} 1-\mathrm{H} 1)$, starting acquisition $2 \mathrm{~min}$ after sample preparation in: control $10 \% \mathrm{v} / \mathrm{v} \mathrm{KO}_{2} / \mathrm{DMSO}$ in the buffer (A1); $\mathrm{KO}_{2}$ /DMSO in the presence of $25 \mu \mathrm{M} \mathrm{R}-\mathrm{Se}$ (B1); $25 \mu \mathrm{MR}-\mathrm{S}$ (C1); $25 \mu \mathrm{M} \mathrm{R}-\mathrm{O}$ (D1); $50 \mu \mathrm{M} \mathrm{H} \mathrm{H}_{2} \mathrm{~S}$ (E1); a mixture of $25 / 50 \mu \mathrm{M} / \mu \mathrm{M} \mathrm{R}-\mathrm{Se} / \mathrm{H}_{2} \mathrm{~S}$ (F1); a mixture of $25 / 50 \mu \mathrm{M} / \mu \mathrm{M}$ R-S/ $\mathrm{H}_{2} \mathrm{~S}$ (G1) and a mixture of $25 / 50 \mu \mathrm{M} / \mu \mathrm{M} \mathrm{R}-\mathrm{O} / \mathrm{H}_{2} \mathrm{~S}(\mathrm{H} 1)$. The spectra $\mathrm{A} 2-\mathrm{H} 2$ show details of the accumulated first ten $\mathrm{A} 1-\mathrm{H} 1$ spectra. The spectra $\mathrm{A} 3-\mathrm{H} 3$ show details of the accumulated last five $\mathrm{A} 1-\mathrm{H} 1$ spectra. The intensities of the time-dependent EPR spectra (A1-H1) and detailed spectra (A2-H2 and $\mathrm{A} 3-\mathrm{H} 3)$ are comparable, as they were measured under identical EPR settings.

of ${ }^{-B M P O}-\mathrm{OOH}$ to ${ }^{-\mathrm{BMPO}-\mathrm{OH}}$ and scavenge both ${ }^{\circ} \mathrm{BMPO}-$ adducts. However, we cannot exclude the possibility of trapping an unknown radical by BMPO which decomposed to ${ }^{\circ} \mathrm{BMPO}-\mathrm{OH}$ before measurement of the sample. Our data suggest that R-S, $\mathrm{H}_{2} \mathrm{~S} / \mathrm{R}$-Se and $\mathrm{H}_{2} \mathrm{~S} / \mathrm{R}-\mathrm{S}$ have high potency to scavenge different radicals.

To summarize this section, taking into account the ability of the phthalic derivatives to reduce the ${ }^{\circ}$ PTIO radical, we have studied also how these derivatives interact with $\mathrm{O}_{2}{ }^{\bullet-}$, observing how they interfere with the formation of the ${ }^{\bullet} \mathrm{BMPO}-\mathrm{OOH}$ adduct in the presence of $\mathrm{KO}_{2}$ and BMPO. In this experiment, R-Se and R-O showed a minor interaction with the $\mathrm{O}_{2}{ }^{\bullet-}$ radical, whereas R-S significantly decreased the formation of the ${ }^{-\mathrm{BMPO}-\mathrm{OOH}}$ adducts. Interestingly, the addition of $\mathrm{H}_{2} \mathrm{~S}$ to R-Se and to R-S 

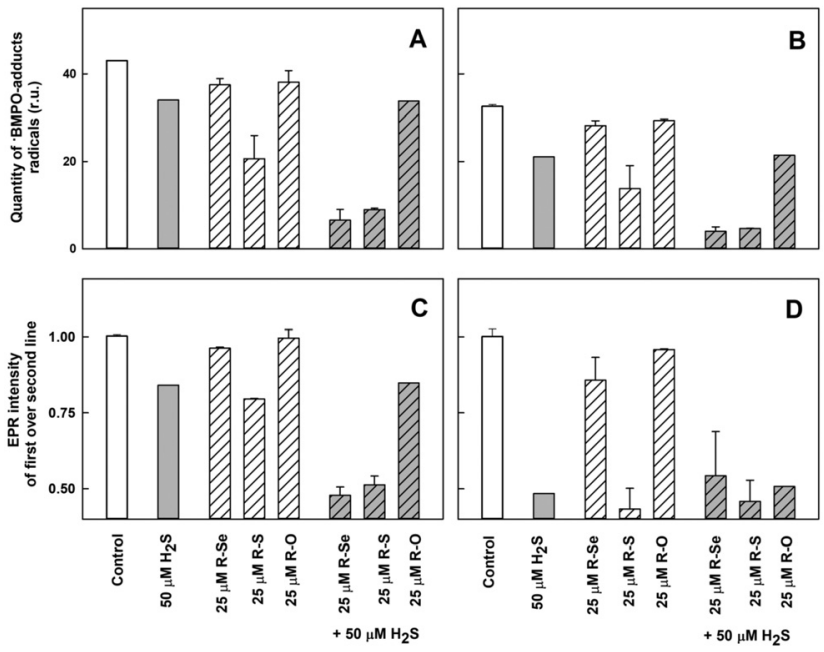

Fig. 13 The effects of the compounds on the $-\mathrm{BMPO}$-adduct radicals The effects of the compounds $(25 \mu \mathrm{M})$ and their mixture with $\mathrm{H}_{2} \mathrm{~S}(50 \mu \mathrm{M})$ on the quantity of the $\cdot \mathrm{BMPO}$-adduct radicals (double integral of the EPR spectra from Fig. 12) in the presence of $10 \% \mathrm{v} / \mathrm{v}$ saturated $\mathrm{KO}_{2} / \mathrm{DMSO}$ solution. Average radical quantity during 2-9 (A, from Fig. 12A2-H2) and 10-13 ( $B$, from Fig. 12A3-H3) min after sample preparation. The effects of the compounds $(25 \mu \mathrm{M})$ and their mixture with $\mathrm{H}_{2} \mathrm{~S}(50 \mu \mathrm{M})$ on the ratio of the EPR intensity of the first over the second line spectra of the ${ }^{-B M P O}$ adduct radicals (data from Fig. 12). Average ratio during 2-9 (C, from Fig. 12A2-H2) and 10-13 (D, from Fig. 12A3-H3) min after sample preparation. Buffer: $50 \mathrm{mM}$ sodium phosphate, $0.1 \mathrm{mM}$ DTPA, $\mathrm{pH} 7.4,37^{\circ} \mathrm{C}$. Mean \pm SEM, $n=2$.

significantly enhances their capacity to decrease the formation of the ${ }^{B M P O-O O H}$ adduct, again highlighting the enhanced activity of the products of the interaction between $\mathrm{H}_{2} \mathrm{~S}$ and R-Se: the presence of both Se and $\mathrm{S}$ atoms seems to be crucial for all these activities.

\section{Final discussion}

At the sight of the results presented herein, we suggest that the products of the $\mathrm{H}_{2} \mathrm{~S}$ or GSH interaction with R-Se, having free radical scavenging and pDNA cleavage activities, can also affect intracellular molecules other than DNA. Based on the wellknown consequences of oxidative stress, protein oxidation is also highly expected. We are aware of the fact that many more effects should be examined to obtain a more complete picture of the action of the products of the $\mathrm{H}_{2} \mathrm{~S}$ or GSH interaction with $\mathrm{R}$-Se and our intention is to present these promising initial results.

In summary, the results confirm our initial hypothesis: selenoanhydride ( $\mathrm{R}-\mathrm{Se}$ ) can act as a $\mathrm{H}_{2} \mathrm{Se}$ donor, serving as a prodrug that enables the internalisation of selenium into cells, and the subsequent release of $\mathrm{H}_{2} \mathrm{Se}$ and ionic species of Se inside the cell. Besides, we have proven that $\mathrm{H}_{2} \mathrm{~S}$ and GSH interact with R-Se, and that the intermediates and/or products of this interaction have significant properties to reduce (scavenge) the - сPTIO and superoxide $\left(\mathrm{O}_{2}{ }^{-}\right)$radicals or their derivatives and to cleave pDNA. The antioxidant (reducing) properties observed of the intermediates and/or products of the $\mathrm{H}_{2} \mathrm{~S} / \mathrm{R}$-Se and GSH/R-Se interaction to reduce ${ }^{\circ} \mathrm{CPTIO}$, scavenge $\mathrm{O}_{2}{ }^{\cdot-}$ and decompose
-BMPO-OOH to ${ }^{-B M P O-O H}$, indicate that they may modulate redox properties and free radical signalling. However, qualifying the significance of these observations is a challenge for future research.

\section{Experimental}

\section{Chemical synthesis of the anhydride-derivatives}

R-Se and R-S (Fig. 1) were synthetized according to a procedure based on the one previously described in the literature, ${ }^{49}$ with minor modifications, whereas R-O was commercially available. Briefly, a suspension of grey selenium (for R-Se) or elemental sulfur (for R-S) in water-free tetrahydrofuran is reduced by dropwise addition of lithium aluminium hydride. Once the reaction is completed (visible by the ceasing of the generation of molecular hydrogen), phthaloyl chloride is added to the reaction and left reacting till the end of the reaction (usually $1 \mathrm{~h}$ ). Then, the solution is filtered to eliminate the metallic salts generated during the process, and over the filtrate, $10 \mathrm{ml}$ of concentrated sulfuric acid is added dropwise. The mixture is left reacting and the solid formed is filtered and washed with chloroform. The product isolated from the organic fraction is recrystallized in hexane.

The structure of the compounds R-Se and R-S was confirmed by ${ }^{1} \mathrm{H}-\mathrm{NMR}$, and their purity by LC-MS. Spectra are provided in the ESI $\dagger$ and they are in accordance with the literature. The purity of both compounds was $100 \%$ according to LC-MS (see data in the ESI $\dagger$ ), so both derivatives were suitable for biological evaluation as they accomplished the 95\% purity considered as the minimum threshold purity value required for biological assays. The chemical reactions of this synthetic procedure are shown in Fig. 1. It is quite interesting to see how the reaction normally used to get oxygen anhydrides (dehydration of phthalic acid) also serves to synthesize the sulfur and selenium anhydride analogues. What is more, it is noteworthy to point out the selectivity of the formation of the respective thio- and selenoanhydride when an oxygen atom is bound to the second carbonyl of the intermediate chalcogen phthalate.

In previous work in a $\mathrm{PhD}$ dissertation, ${ }^{57}$ to learn more about the reactivity of different phthalic derivatives to form phthalic selenoanhydride (R-Se) following this procedure, a synthetic study was performed. R-Se was synthesized according to the procedure mentioned above, departing from phthaloyl chloride and using lithium aluminium hydride for the reaction. The yield before recrystallization in this case was $94 \%$. When the reaction was carried out using water as a solvent and employing sodium borohydride as a reducing agent, the yield before recrystallization was $47 \%$. The reaction could also use different phthalic derivatives as substrates (always employing lithium aluminium hydride), in this case with different yields. We explored phthalic anhydride and $N$-hydroxyphthalimide, achieving yields of $16 \%$ and $62 \%$, respectively. Interestingly (unpublished results), phthalimide did not render R-Se after dehydration with sulfuric acid. It seems that a selenazine is formed instead of the selenoanhydride, obtaining $1 H$-benzo[d][1,2]selenazine-1,4(3H)-dione. Unfortunately, this 
compound could not be obtained with a satisfactory purity and more research needs to be done to isolate and characterize this compound.

For the pDNA cleavage assay, the anhydride-derivatives were dissolved in ultrapure deionized water at a $1 \mathrm{mM}$ final concentration by vortexing and 1 min water bath sonication, subsequently aliquoted and stored at $-80{ }^{\circ} \mathrm{C}$ before their use. For UV-vis, EPR and ESI studies, the anhydride-derivatives were dissolved in anhydrous DMSO at a $50 \mathrm{mM}$ concentration, aliquoted and stored at $-80{ }^{\circ} \mathrm{C}$ before being used.

\section{ESI-MS measurement}

Saturated R-Se was prepared in $50 \%$ methanol $/ \mathrm{H}_{2} \mathrm{O}$, vortexed for 2-3 min, sonicated in a water bath for 1-2 min and centrifuged for $2 \mathrm{~min}$. The sample without and with $7 \mathrm{mM} \mathrm{Na}_{2} \mathrm{~S}(\sim 9 \mathrm{pH})$ was incubated for $1 \mathrm{~min}$ at $37^{\circ} \mathrm{C}$ and $55 \mu \mathrm{l}$ of the supernatant was used to measure ESI-MS spectra (Orbitrap Elite, ThermoScientific).

\section{Chemicals for UV-vis and EPR measurements}

The studied compounds R-Se, R-S and R-O in DMSO (50 mM) were used after thawing. The spin trap 5-tert-butoxycarbonyl-5methyl-1-pyrroline- $N$-oxide (BMPO, $100 \mathrm{mM}$, ENZO Life Sciences AG, Switzerland) was prepared in deionized $\mathrm{H}_{2} \mathrm{O}$, stored at $-80{ }^{\circ} \mathrm{C}$ and used after thawing. The radical 2-(4-carboxyphenyl)4,4,5,5-tetramethylimidazoline-1-oxyl-3-oxide ( ${ }^{\bullet} \mathrm{cPTIO}, 10 \mathrm{mM}$, Cayman 81540 or Sigma C221) in deionized $\mathrm{H}_{2} \mathrm{O}$ was stored at $-20{ }^{\circ} \mathrm{C}$ for several weeks. $\mathrm{Na}_{2} \mathrm{~S}$ as a source of $\mathrm{H}_{2} \mathrm{~S}(100 \mathrm{mM}$; SB01, DoJindo, Japan) was prepared in deionized $\mathrm{H}_{2} \mathrm{O}$, stored at $-80{ }^{\circ} \mathrm{C}$ and used after thawing. $\mathrm{Na}_{2} \mathrm{~S}$ dissociates in solution and reacts with $\mathrm{H}^{+}$to yield $\mathrm{H}_{2} \mathrm{~S}, \mathrm{HS}^{-}$and a trace of $\mathrm{S}^{2-}$. We use the term $\mathrm{H}_{2} \mathrm{~S}$ to encompass the total mixture of $\mathrm{H}_{2} \mathrm{~S}, \mathrm{HS}^{-}$and $\mathrm{S}^{2-}$. To $\mathrm{Na}_{2} \mathrm{Se}$ powder (Alfa Aesar, 36187, stored under argon) $\mathrm{H}_{2} \mathrm{O}$ was added, and in $10 \mathrm{~s}$ an aliquot of the stock $\mathrm{Na}_{2} \mathrm{Se}$ solution (10 $\mathrm{mM})$ was added to a UV-vis cuvette containing the studied compounds. $100 \mathrm{mM}$ sodium phosphate buffer supplemented with $100 \mu \mathrm{M}$ DTPA, pH 7.4, $37{ }^{\circ} \mathrm{C}$, was employed for UV-vis experiments. 50 and $25 \mathrm{mM}$ sodium phosphate buffer, supplemented with 100 and $50 \mu \mathrm{M}$ DTPA (diethylenetriaminepentaacetic acid), $\mathrm{pH} 7.4,37{ }^{\circ} \mathrm{C}$ was used for electron paramagnetic resonance (EPR) studies.

\section{UV-vis of $\bullet$ cPTIO}

To a basic 900-990 $\mu$ l solution of $100 \mathrm{mM}$ sodium phosphate, $100 \mu \mathrm{M}$ DTPA buffer ( $\left.\mathrm{pH} 7.4,37^{\circ} \mathrm{C}\right)$ the required aliquots of $100 \mu \mathrm{M}{ }^{\bullet}$ cPTIO and $\mathrm{Na}_{2} \mathrm{~S}$ were added to obtain the desired final concentrations of ${ }^{-}$CPTIO and $\mathrm{Na}_{2} \mathrm{~S}$. Then, the UV-vis spectra (900-190 nm) were recorded, $3 \times 30 \mathrm{~s}$. The studied compounds R-Se, R-S and R-O (50 mM in DMSO), firstly dissolved in $50 \mu \mathrm{l}$ buffer and vortexed for $3 \mathrm{~s}$, were added and the spectra were recorded every $30 \mathrm{~s}$ for $20 \mathrm{~min}$ using a Shimadzu 1800 (Kyoto, Japan) spectrometer at $37{ }^{\circ} \mathrm{C}$ (the blank was $\mathrm{H}_{2} \mathrm{O}$ ). For our study, the ${ }^{\bullet}$ cPTIO extinction coefficient at $560 \mathrm{~nm}$ of $920 \mathrm{M}^{-1} \mathrm{~cm}^{-1}$ was used. Scavenging of the ${ }^{\circ} \mathrm{CPTIO}$ radical by $\mathrm{Na}_{2} \mathrm{~S}\left(\mathrm{H}_{2} \mathrm{~S}\right)$ or $\mathrm{GSH}$ and its mixture with the studied compounds R-Se, R-S and R-O was determined as a decrease of absorbance at 356 and $560 \mathrm{~nm}$ (the absorption maximum of ${ }^{\bullet}$ cPTIO) after subtraction of the baseline absorbance, which was determined at 730 or $420 \mathrm{~nm}$, respectively. ${ }^{42}$

\section{Plasmid DNA cleavage}

The pDNA cleavage assay, which detects a disruption of the sugar-phosphate backbone of DNA, was used to study if the products of the $\mathrm{H}_{2} \mathrm{~S} / \mathrm{R}-\mathrm{Se}$ and/or $\mathrm{GSH} / \mathrm{R}-\mathrm{Se}$ interaction can directly attack pDNA. In this assay, even a single hit is trapped, as it converts the circular supercoiled DNA molecule into its nicked relaxed circular form. These two forms display distinct mobility in agarose gels, and therefore they can easily be distinguished and quantified.

The pBR322 vector (4.361 kb, New England Biolabs, N3033L) was used in the pDNA cleavage assay. In this assay, all samples contained $200 \mathrm{ng}$ of pDNA in a final volume of $20 \mu \mathrm{l}$ of buffer composed of $25 \mathrm{mM}$ sodium phosphate and $50 \mu \mathrm{M}$ DTPA ( $\mathrm{pH}$ 7.4). Three different assay conditions were used: (i) pDNA per se (control), (ii) pDNA + phthalic-anhydride derivatives, and (iii) pDNA + anhydride-derivative $+\mathrm{Na}_{2} \mathrm{~S}$ or GSH. The resulting mixtures were incubated for $30 \mathrm{~min}$ at $37{ }^{\circ} \mathrm{C}$. Afterwards, the reaction mixtures were subjected to $0.6 \%$ agarose gel electrophoresis. The samples were electrophoresed in TBE buffer $(89 \mathrm{mM}$ Tris, $89 \mathrm{mM}$ boric acid, $2 \mathrm{mM}$ EDTA, pH 8.0) at $5.5 \mathrm{~V} \mathrm{~cm}^{-1}$ for $2 \mathrm{~h}$. The gel was stained with Gel Red ${ }^{\mathrm{TM}}$ nucleic acid gel stain. Finally, the gels were photographed using a UV transilluminator. To quantify the pDNA cleavage efficiency, the integrated densities of two identified pBR322 forms (a supercoiled and a nicked circular form) in each lane were quantified using Total Lab TL100 image analysis software (Nonlinear Dynamic Ltd, USA).

\section{EPR of •BMPO-adducts}

To study the ability of R-Se, R-S and R-O without and with $\mathrm{H}_{2} \mathrm{~S}$ to scavenge the $\mathrm{O}_{2}{ }^{\bullet-}$ radical produced in $\mathrm{DMSO} / \mathrm{KO}_{2}$ solution, sample preparation and EPR measurements were conducted in accordance with previously reported protocols. ${ }^{42}$ A solution (final concentrations) of BMPO $(20 \mathrm{mM})$ and DTPA $(100 \mu \mathrm{M})$ in sodium phosphate buffer (50 mM, pH 7.4) was incubated for $1 \mathrm{~min}$ at $37{ }^{\circ} \mathrm{C}$. An aliquot of the compounds studied was added, followed by the addition of $\mathrm{Na}_{2} \mathrm{~S}$ in $3 \mathrm{~s}$ and saturated $\mathrm{KO}_{2} / \mathrm{DMSO}$ solution (10\% v/v DMSO/final buffer) $3 \mathrm{~s}$ later. The sample was mixed for $5 \mathrm{~s}$ and the first EPR spectrum was recorded $2 \mathrm{~min}$ after the addition of $\mathrm{KO}_{2} / \mathrm{DMSO}$ solution at $37^{\circ} \mathrm{C}$. Sets of individual EPR spectra of the ${ }^{\bullet} \mathrm{BMPO}$ spin-adducts were recorded as 15 sequential scans, each $42 \mathrm{~s}$, with a total time of $11 \mathrm{~min}$. Each experiment was repeated at least twice. EPR spectra of the ${ }^{\bullet}$ BMPO spin-adducts were measured on a Bruker EMX spectrometer, X-band $\sim 9.4 \mathrm{GHz}, 335.15 \mathrm{mT}$ central field, $8 \mathrm{mT}$ scan range, $20 \mathrm{~mW}$ microwave power, $0.1 \mathrm{mT}$ modulation amplitude, $42 \mathrm{~s}$ sweep time, $20.48 \mathrm{~ms}$ time constant, and $20.48 \mathrm{~ms}$ conversion time at $37^{\circ} \mathrm{C}$.

The relative quantity of the ${ }^{\circ} \mathrm{BMPO}$-adduct radicals was calculated as a double integral of the EPR spectra. Since the EPR spectra were mostly low intensity, which did not permit spectral simulation, to quantify the relative ratio of the ${ }^{\bullet} \mathrm{BMPO}-$ $\mathrm{OOH} /{ }^{\bullet} \mathrm{BMPO}$-adducts, the ratio of the EPR intensity of the first line over the second line was used. The ratio is $\sim 1$ at $\sim 100 \%$ of 
BMPO-OOH (Fig. 12A2) and $~ 0.5$ at $\sim 0 \%$ of ${ }^{\bullet} \mathrm{BMPO}-O O H^{42} \mathrm{~A}$ lower ratio (lower than 1) indicates a higher concentration of other ${ }^{\bullet} \mathrm{BMPO}$-adducts, in which mostly ${ }^{\bullet} \mathrm{BMPO}-\mathrm{OH}$ radicals are present.

\section{Conclusions}

Understanding the molecular mechanism of the biological effects of phthalic-anhydride derivatives could lead to development of more efficient drugs for treatment of cancer and ROS related diseases. To achieve this, we found that phthalicanhydride derivatives R-Se, R-S, R-O and R-OH $(\leq 50 \mu \mathrm{M})$ on their own have minor potency to reduce/scavenge radicals or cleave pDNA. However, the potency of R-Se and R-S, but not R-O or R-OH, significantly increased after interacting with $\mathrm{H}_{2} \mathrm{~S}$ and GSH.

Our in vitro data revealed unique properties of the $\mathrm{H}_{2} \mathrm{~S} / \mathrm{R}-\mathrm{Se}$, GSH/R-Se and $\mathrm{H}_{2} \mathrm{~S} / \mathrm{R}-\mathrm{S}$ mixtures to reduce the ${ }^{\circ} \mathrm{cPTIO}$ and superoxide radicals. The unique potency of the $\mathrm{H}_{2} \mathrm{~S} / \mathrm{R}$-Se mixture to cleave pDNA has a bell-shaped dependence on the $\mathrm{H}_{2} \mathrm{~S}$ and GSH concentrations, whereas the potency of $\mathrm{H}_{2} \mathrm{~S} / \mathrm{R}-\mathrm{S}$ increased linearly with $\mathrm{H}_{2} \mathrm{~S}$, but did not increase with the GSH concentration. The results underline that the interactions of R-Se and R-S with $\mathrm{H}_{2} \mathrm{~S}$ and $\mathrm{GSH}$ enhanced significantly the different activities monitored, thus indicating that the intermediates and/or the products of the interaction of R-Se and R-S with endogenous $\mathrm{H}_{2} \mathrm{~S}$ and $\mathrm{GSH}$, which appear to include reactive selenium species such as $\mathrm{H}_{2} \mathrm{Se}$, have significant antioxidant properties and that they can damage DNA. These findings may contribute to a more-in-depth understanding of the unique biological effects reported so far for R-Se and R-S. Besides, these findings open a new so far unexplored approach to study the action of Se-containing compounds. These experiments, for example, can be applied to the different selenium species that have been used until now in supplementation, to ascertain which ones have more ability to interact with GSH and $\mathrm{H}_{2} \mathrm{~S}$. This is of crucial importance, as it would enable detecting new compounds that could behave as Se-based redox modulators in potential Se supplementation. An example would be the phthalic selenoanhydride (R-Se) reported in this work, which retains the capacity of sodium selenite to react with key components of the redox thiolstat (such as GSH and $\mathrm{H}_{2} \mathrm{~S}$ ) and simultaneously, according to previous work, shows lower toxicity against non-tumour cells.

\section{Author contributions}

Conceptualization, E. D.-A., C. J., M. C., and K. O.; methodology, K. O., M. C., and V. B.; validation, K. O., M. C., V. B., A. M., M. G., and E. D.-A.; formal analysis, A. M., and K. O.; investigation, A. M., M. G., A. K., V. B., L. K., P. B., M. C., K. O., and E. D.-A.; resources, A. K., C. J., and E. D.-A.; writing - original draft preparation, K. O., M. C., and E. D.-A.; visualization, K. O., A. M., M. G., and E. D.-A.; supervision, K. O., C. J., M. C., and E. D.-A.; project administration, K. O., C. J., M. C., and E. D.-A.; funding acquisition, K. O.

\section{Conflicts of interest}

There are no conflicts to declare.

\section{Acknowledgements}

This research was funded by the Slovak Research \& Development Agency, grant numbers APVV-15-0371, 15-0565 and 17-0384, and the Scientific Grant Agency of the Slovak Republic, grant numbers VEGA 1/0026/18, 2/0079/19, 2/0014/17 and $2 / 0053 / 19$. The authors would also like to acknowledge the financial support of the Agencia Estatal Consejo Superior de Investigaciones Científicas (Spain, project 201780I027) and of the University of Saarland (through the Landesforschungsförderungsprogramm (LFPP) of the state of Saarland, Grant No. WT/2-LFFP 16/01). We also acknowledge the INTERREG-VA GR program (BIOVAL, Grant No. 4-09-21) and the NutRedOx (COST Project CA16112), as well as the support of the Erasmus+ program. We also thank Prof. Dr Anna K. H. Hirsch and Dr Eleonora Diamanti from Helmholtz Institute for Pharmaceutical Research in Saarland (HIPS) for helping with MS spectra measurements.

\section{Notes and references}

1 S. J. Fairweather-Tait and K. Cashman, in Nutrition for the Primary Care Provider. World Rev. Nutr. Diet., ed. D. M. Bier, J. Mann, D. H. Alpers, H. H. E. Vorster and M. J. Gibney, Karger AG, Basel, Switzerland, 2015, ch. 8, vol. 111, pp. 45-52.

2 S. Li, T. Xiao and B. Zheng, Sci. Total Environ, 2012, 421-422, 31-40.

3 S. Stranges, J. R. Marshall, R. Natarajan, R. P. Donahue, M. Trevisan, G. F. Combs, F. P. Cappuccio, A. Ceriello and M. E. Reid, Ann. Intern. Med., 2007, 147, 217-223.

4 D. L. Hatfield, M. H. Yoo, B. A. Carlson and V. N. Gladyshev, Biochim. Biophys. Acta, Gen. Subj., 2009, 1790, 1541-1545.

5 J. C. Avery and P. R. Hoffmann, Nutrients, 2018, 10, 1203.

6 N. Shang, X. Wang, Q. Shu, H. Wang and L. Zhao, J. Nanosci. Nanotechnol., 2019, 19, 1875-1888.

7 K. M. Peters, B. A. Carlson, V. N. Gladyshev and P. A. Tsuji, Free Radical Biol. Med., 2018, 127, 14-25.

8 V. Gandin, P. Khalkar, J. Braude and A. P. Fernandes, Free Radical Biol. Med., 2018, 127, 80-97.

9 M. Bodnar, M. Szczyglowska, P. Konieczka and J. Namiesnik, Crit. Rev. Food Sci. Nutr., 2016, 56, 36-55.

10 A. Tarze, M. Dauplais, I. Grigoras, M. Lazard, N. T. Ha Duong, F. Barbier, S. Blanquet and P. Plateau, J. Biol. Chem., 2007, 282, 8759-8767.

11 A. P. Fernandes and V. Gandin, Biochim. Biophys. Acta, Gen. Subj., 2015, 1850, 1642-1660.

12 J. J. An, K. J. Shi, W. Wei, F. Y. Hua, Y. L. Ci, Q. Jiang, F. Li, P. Wu, K. Y. Hui, Y. Yang and C. M. Xu, Cell Death Dis., 2013, 4, e973.

13 G. Nilsonne, X. Sun, C. Nyström, A. K. Rundlöf, A. Potamitou Fernandes, M. Björnstedt and K. Dobra, Free Radical Biol. Med., 2006, 41, 874-885. 
14 J. Brozmanová, D. Mániková, V. Vlčková and M. Chovanec, Arch. Toxicol., 2010, 84, 919-938.

15 E. Jablonska and M. Vinceti, J. Environ. Sci. Health, Part C: Environ. Carcinog. Ecotoxicol. Rev., 2015, 33, 328-368.

16 H. J. Reich and R. J. Hondal, ACS Chem. Biol., 2016, 11, 821-841.

17 R. Mousa, R. Notis Dardashti and N. Metanis, Angew. Chem., Int. Ed., 2017, 56, 15818-15827.

18 C. Jacob, G. I. Giles, N. M. Giles and H. Sies, Angew. Chem., Int. Ed., 2003, 42, 4742-4758.

19 L. Sancineto, M. Palomba, L. Bagnoli, F. Marini and C. Santi, Curr. Org. Chem., 2016, 20, 122-135.

20 D. Bartolini, L. Sancineto, A. Fabro de Bem, K. D. Tew, C. Santi, R. Radi, P. Toquato and F. Galli, in Advances in Cancer Research, ed. K. D. Tew and F. Galli, Academic Press Inc., Cambridge, USA, 2017, ch. 10, vol. 136, pp. 259-302.

21 C. Santi, C. Tomassini and L. Sancineto, Chimia, 2017, 71, 592-595.

22 M. Álvarez-Pérez, W. Ali, M. A. Marć, J. Handzlik and E. Domínguez-Álvarez, Molecules, 2018, 23, 628.

23 W. Ali, M. Álvarez-Pérez, M. A. Marć, N. Salardón-Jiménez, J. Handzlik and E. Domínguez-Álvarez, Curr. Pharmacol. Rep., 2018, 4, 468-481.

24 S. Misra, M. Boylan, A. Selvam, J. E. Spallholz and M. Björnstedt, Nutrients, 2015, 7, 3536-3556.

25 C. M. Weekley and H. H. Harris, Chem. Soc. Rev., 2013, 42, 8870-8894.

26 R. Terazawa, D. R. Garud, N. Hamada, Y. Fujita, T. Itoh, Y. Nozawa, K. Nakane, T. Deguchi, M. Koketsu and M. Ito, Bioorg. Med. Chem., 2010, 18, 7001-7008.

27 B. Romano, D. Plano, I. Encío, J. A. Palop and C. Sanmartín, Bioorg. Med. Chem., 2015, 23, 1716-1727.

28 Y. Zakharia, A. Bhattacharya and Y. M. Rustum, Oncotarget, 2018, 9, 10765-10783.

29 C. Santi, C. Tidei, C. C. Scalera, M. Piroddi and F. Galli, Curr. Chem. Biol., 2013, 7, 25-36.

30 D. Bartolini, M. Piroddi, C. Tidei, S. Giovagnoli, D. Pietrella, Y. Manevich, K. D. Tew, D. Giustarini, R. Rossi, D. M. Townsend, C. Santi and F. Galli, Free Radical Biol. Med., 2015, 78, 56-65.

31 M. M. Rahman, R. A. Uson-Lopez, M. T. Sikder, G. Tan, T. Hosokawa, T. Saito and M. Kurasaki, Chemosphere, 2018, 196, 453-466.

32 M. Mix, N. Ramnath, J. Gomez, C. De Groot, S. Rajan, S. Dibaj, W. Tan, Y. Rustum, M. B. Jameson and A. K. Singh, World J. Clin. Oncol., 2015, 6, 156-165.

33 D. Mániková, L. M. Letavayová, D. Vlasáková, P. Košík, E. C. Estevam, M. J. Nasim, M. Gruhlke, A. Slusarenko, T. Burkholz, C. Jacob and M. Chovanec, Molecules, 2014, 19, 12258-12279.

34 C. Sanmartín, D. Plano, M. Font and J. A. Palop, Curr. Cancer Drug Targets, 2011, 11, 496-523.

35 R. Wang, Physiol. Rev., 2012, 92, 791-896.

36 C. Szabo and A. Papapetropoulos, Pharmacol. Rev., 2017, 69, 497-564.

37 H. Kimura, Antioxid. Redox Signaling, 2015, 22, 362-376.
38 M. Whiteman, J. S. Armstrong, S. H. Chu, S. Jia-Ling, B. S. Wong, N. S. Cheung, B. Halliwell and P. K. Moore, J. Neurochem., 2004, 90, 765-768.

39 M. Whiteman, N. S. Cheung, Y. Z. Zhu, S. H. Chu, J. L. Siau, B. S. Wong, J. S. Armstrong and P. K. Moore, Biochem. Biophys. Res. Commun., 2005, 326, 794-798.

40 A. Staško, V. Brezová, M. Zalibera, S. Biskupič and K. Ondriaš, Free Radical Res., 2009, 43, 581-593.

41 B. Olas, Chem.-Biol. Interact., 2014, 217, 46-56.

42 A. Misak, M. Grman, Z. Bacova, I. Rezuchova, S. Hudecova, E. Ondriasova, O. Krizanova, V. Brezova, M. Chovanec and K. Ondrias, Nitric oxide, 2018, 76, 136-151.

43 C. Szabo, C. Coletta, C. Chao, K. Módis, B. Szczesny, A. Papapetropoulos and M. R. Hellmich, Proc. Natl. Acad. Sci. U. S. A., 2013, 110, 12474-12479.

44 D. Wu, W. Si, M. Wang, S. Lv, A. Ji and Y. Li, Nitric oxide, 2015, 50, 38-45.

45 J. Breza Jr., A. Soltysova, S. Hudecova, A. Penesova, I. Szadvari, P. Babula, B. Chovancova, L. Lencesova, O. Pos, J. Breza, K. Ondrias and O. Krizanova, BMC Cancer, 2018, 18, 591.

46 V. I. Lushchak, J. Amino Acids, 2012, 736837.

47 C. Gaucher, A. Boudier, J. Bonetti, I. Clarot, P. Leroy and M. Parent, Antioxidants, 2018, 7, 62.

48 A. Kharma, M. Grman, A. Misak, E. Domínguez-Álvarez, M. J. Nasim, K. Ondrias, M. Chovanec and C. Jacob, Molecules, 2019, 24, 1359.

49 E. Domínguez-Álvarez, D. Plano, M. Font, A. Calvo, C. Prior, C. Jacob, J. A. Palop and C. Sanmartín, Eur. J. Med. Chem., 2014, 73, 153-166.

50 M. J. Nasim, W. Ali, E. Domínguez-Álvarez, E. N. da Silva Júnior, R. S. Z. Saleem and C. Jacob, in Organoselenium Compounds in Biology and Medicine: Synthesis, Biological and Therapeutic Treatments, ed. V. K. Jain and K. I. Priyadarsini, The Royal Society of Chemistry, Croydon, UK, 2018, ch. 10, pp. 277-302.

51 M. Gajdács, G. Spengler, C. Sanmartín., M. A. Marć, J. Handzlik and E. Domínguez-Álvarez, Bioorg. Med. Chem. Lett., 2017, 27, 797-802.

52 E. Domínguez-Álvarez, M. Gajdács, G. Spengler, J. A. Palop, M. A. Marć, K. Kieć-Kononowicz, L. Amaral, J. Molnár, C. Jacob, J. Handzlik and C. Sanmartín, Bioorg. Med. Chem. Lett., 2016, 26, 2821-2824.

53 M. M. Cortese-Krott, G. G. C. Kuhnle, A. Dyson, B. O. Fernandez, M. Grman, J. F. DuMond, M. P. Barrow, G. McLeod, H. Nakagawa, K. Ondrias, P. Nagy, S. B. King, J. E. Saavedra, L. K. Keefer, M. Singer, M. Kelm, A. R. Butler and M. Feelisch, Proc. Natl. Acad. Sci. U. S. A., 2015, 112, E4651-E4660.

54 M. T. Zimmerman, C. A. Bayse, R. R. Ramoutar and J. L. Brumaghim, J. Inorg. Biochem., 2015, 145, 30-40.

55 Y. H. Liu, M. Lu, L. F. Hu, P. T. H. Wong, G. D. Webb and J. S. Bian, Antioxid. Redox Signaling, 2012, 17, 141-185.

56 H. Zhao, J. Joseph, H. Zhang, H. Karoui and B. Kalyanaraman, Free Radical Biol. Med., 2001, 31, 599-606.

57 E. Domínguez-Álvarez, PhD Dissertation, University of Navarra, Spain, 2012. 